\title{
Quantifying Streamflow Depletion from Groundwater Pumping: A Practical Review of Past and Emerging Approaches for Water Management
}

Authors: Samuel C. Zipper, William H. Farmer, Andrea Brookfield, Hoori Ajami, Howard W.

Affiliations: Kansas Geological Survey (Zipper), University of Kansas, Lawrence, KS, USA;

6 U.S. Geological Survey (Farmer), Denver, CO, USA; Department of Earth and Environmental

Sciences (Brookfield), University of Waterloo, Waterloo, ON, Canada; Department of

8 Environmental Sciences (Ajami), University of California, Riverside, CA, USA; U.S. Geological

9 Survey Upper Midwest Water Science Center (Reeves), Lansing, MI, USA; Department of

10 Natural Resources and Society (Wardropper), University of Idaho, Moscow, ID, USA; U.S.

11 Geological Survey MD-DE-DC Water Science Center (Hammond), Baltimore, MD, USA;

12 Department of Civil Engineering (Gleeson), University of Victoria, Victoria, BC, Canada;

13 Department of Earth Systems Science and Center on Food Security and the Environment

14 (Deines), Stanford University, Stanford, CA, USA

15 ORCiD IDs: Zipper (0000-0002-8735-5757), Brookfield (0000-0003-3739-0025), Ajami (0000-

16 0001-6883-7630), Reeves (0000-0001-8057-2081), Hammond (0000-0002-4935-0736), Gleeson

17 (0000-0001-9493-7707), Deines (0000-0002-4279-8765), Farmer (0000-0002-2865-2196),

18 Wardropper (0000-0002-0652-2315)

19 Keywords: streamflow depletion, stream-aquifer interactions, watershed management, decision 20 support systems

21 Research Impact Statement: We categorize common water management questions related to 22 streamflow depletion and develop a set of criteria to guide managers in selecting an appropriate 23 streamflow depletion estimation tool.

24 This is a non-peer-reviewed manuscript submitted to EarthArXiv. The manuscript has been 25 submitted to JAWRA for scientific peer review (revised version submitted in November 2021).

26 Because the manuscript has not yet been approved for publication by the U.S. Geological Survey 27 (USGS), it does not represent any official USGS finding or policy. 
29 ABSTRACT: Groundwater pumping can cause reductions in streamflow ('streamflow

30 depletion') that must be quantified for conjunctive management of groundwater and surface

31 water resources. However, streamflow depletion cannot be measured directly and is challenging

32 to estimate because pumping impacts are masked by streamflow variability due to other factors.

33 Here, we conduct a management-focused review of analytical, numerical, and statistical models

34 for estimating streamflow depletion and highlight promising emerging approaches. Analytical

35 models are easy to implement, but include many assumptions about the stream and aquifer.

36 Numerical models are widely used for streamflow depletion assessment and can represent many

37 processes affecting streamflow, but have high data, expertise, and computational needs.

38 Statistical approaches are a historically underutilized tool due to difficulty in attributing

39 causality, but emerging causal inference techniques merit future research and development. We

40 propose that streamflow depletion-related management questions can be divided into three broad

41 categories (attribution, impacts, and mitigation) that influence which methodology is most

42 appropriate. We then develop decision criteria for method selection based on suitability for local

43 conditions and the management goal, actionability with current or obtainable data and resources,

44 transparency with respect to process and uncertainties, and reproducibility. 
Conjunctive water management, which acknowledges the interconnected nature of groundwater and surface water and manages them as a single resource, is critical to sustain both human society and aquatic and terrestrial ecosystems. Groundwater inflow to streams provides a stable supply of water, which sustains human water needs for domestic use, industry, and agriculture (Gleeson, Cuthbert, et al., 2020; Taylor et al., 2013) and supports ecological communities (Larsen and Woelfle-Erskine, 2018). Streamflow depletion, defined as "a reduction in total streamflow caused by groundwater pumping" (Barlow et al., 2018), can occur in both gaining or losing streams (Figure 1). Streamflow depletion occurs when pumping captures groundwater that otherwise would flow from the aquifer to the stream (increased gains in a gaining stream), reverses the direction of flow at the stream-aquifer interface (transition from gaining to losing stream), or increases the rate of infiltration losses through the streambed (increased losses in a losing stream). For further background and details on streamflow depletion please see Barlow and Leake, (2012).

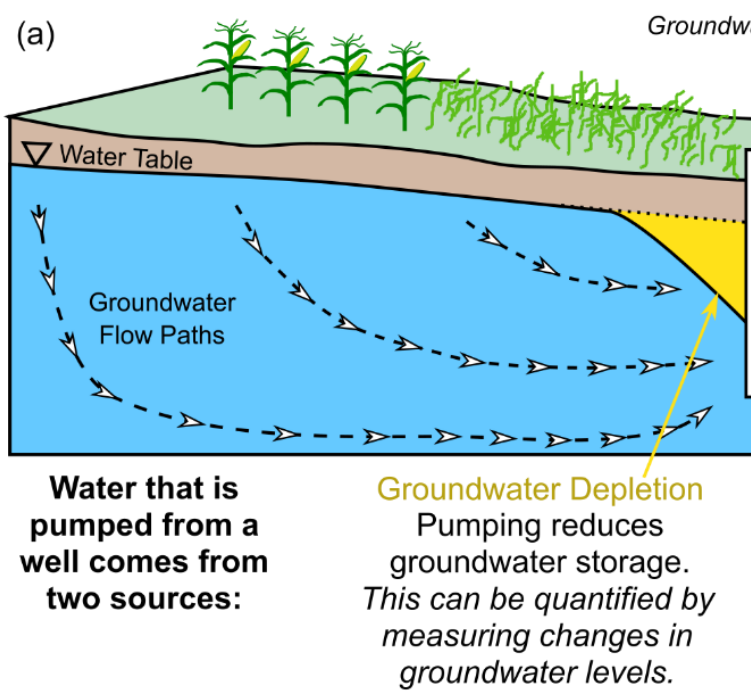
groundwater levels.

Figure 1. Response of an interconnected stream-aquifer system to pumping. (a) Example stream-aquifer cross-section for a gaining stream. Streamflow depletion occurs when groundwater that would have discharged into the stream is captured by the pumping well. Streamflow depletion can also occurring in losing streams. (b) Streamflow depletion is the reduction in streamflow caused by pumping relative to what it would have been in the absence of pumping. Streamflow depletion cannot be directly measured and is challenging to estimate.

Streamflow depletion is particularly problematic when it causes streamflow to drop below environmental flows, defined as "the quantity, timing, and quality of freshwater flows and levels necessary to sustain aquatic ecosystems which, in turn, support human cultures, economies, sustainable livelihoods, and well-being" (Arthington et al., 2018). Streamflow depletion has already impaired environmental flows around the world (Konikow and Leake, 2014; de Graaf et al., 2019), with diverse local impacts including a transition from perennial to intermittent streams (Zimmer et al., 2020; Zipper, Hammond, et al., 2021), impairment of 
surface water right holders (Idaho Water Resource Board, 2019) and collapse of aquatic ecosystems (Perkin et al., 2017). Impairment of environmental flows due to streamflow depletion is anticipated to become more widespread in the future and will be exacerbated by climate change (de Graaf et al., 2019).

Unfortunately, streamflow depletion is challenging to measure directly and, as a result, the extent to which groundwater pumping affects streamflow is unknown or uncertain, even in settings where the hydrology has been previously studied. Quantifying streamflow depletion is hard because significant time lags between pumping and changes in streamflow may exist, and these lags vary as a function of well-stream geometry and aquifer characteristics (Bredehoeft, 2011). Furthermore, the signal of streamflow depletion will be convoluted with all other factors impacting both short-term and long-term streamflow variability (Barlow and Leake, 2012), many of which are difficult to characterize such as surface water diversions, weather variability, reservoir operations, land use change, and climate change. While streamflow depletion can be measured at the scale of an individual stream reach using intensive field measurements (Hunt et al., 2001; Kollet and Zlotnik, 2003; Lee et al., 2017), it is not possible to measure streamflow depletion at the regional scale, nor resolve depletion in individual segments, using observational data alone.

Since regional-scale streamflow depletion cannot be measured, managers must base decisions on streamflow depletion estimates. Three primary approaches for estimating regionalscale streamflow depletion are analytical, numerical, and statistical models. Each approach has strengths and weaknesses for decision support purposes, making the selection of an appropriate method challenging. Analytical models were the first approaches developed for estimating streamflow depletion (Glover and Balmer, 1954; Theis, 1941) and have relatively low data and computational requirements, but contain many simplifying assumptions that reduce their flexibility (Huang et al., 2018; Hunt, 2014). In contrast, numerical models allow for a more realistic representation of groundwater and surface water interactions and are often considered the 'gold standard' for streamflow depletion assessment in that they are expected to be the most accurate, but are complex and require significant time, data, and expertise for their development, and are available only in limited locations (Barlow and Leake, 2012; Fienen, Bradbury, et al., 2018; Fienen et al., 2016; Mehl and Hill, 2010). Finally, statistical models attempt to relate changes in streamflow to potential drivers such as groundwater pumping and climate variability, but are limited in their ability to identify causal relationships (Barlow and Leake, 2012; Karpatne et al., 2019) and to our knowledge have only rarely been used to quantify streamflow depletion. However, use of statistical models in other fields such as climate change attribution suggest that their use may evolve going forward, particularly given recent advances in physics-informed statistical methods (Read et al., 2019).

Quantifying streamflow depletion is important for numerous water management decisions, and water managers must choose among the variety of available approaches by considering their strengths and weaknesses relative to available resources. To serve this process, 
our objective is to review and synthesize the advantages, disadvantages, and uncertainties in streamflow depletion estimation methods to provide water managers with a better foundation to select the most appropriate method(s) based on the management question, hydrogeological setting, data, and resources available. We provide examples to illustrate the relative utility and practicality of these approaches, and while we focus primarily on North American examples, the applicability of this work is global, much like the problem of streamflow depletion (Gleeson and Richter, 2018; de Graaf et al., 2019; Rohde et al., 2017).

In this review, we use the title "water manager" to encompass multiple types of publicly and privately employed decision makers, including staff of organizations like state or provincial water planning or regulation offices, irrigation districts, fish and wildlife organizations, watershed associations, and/or other stakeholders working with these agencies such as environmental consultants or non-governmental organizations. We collected literature and policy for review through several approaches including (1) searching databases (i.e., Web of Science, Google Scholar) with relevant terms such as 'streamflow depletion'; (2) studies with which our group of authors were familiar; and (3) forward and backward citation tracing from studies identified in steps (1) or (2). We also had semi-structured conversations with five stakeholders in the water management area, with specific roles spanning water planning and regulation, environmental consulting and decision support, and environmental non-governmental organizations; more details about these conversations are in Appendix 1. The focus on water management applications and inclusion of recent and emerging methods of streamflow depletion estimation distinguishes this work from the foundational contributions of Barlow and Leake (2012).

Management and policy of interconnected groundwater and surface water

Water management primarily interfaces with streamflow depletion through questions related to changes in surface water flows to ensure water availability for downstream users and/or maintain environmental flows for aquatic ecosystems. Historically, groundwater resources and surface water resources have often been treated separately (Bredehoft and Young 1983; Gleeson et al., 2012), but in recent decades conjunctive water management frameworks that acknowledge the interconnected nature of surface water and groundwater are being applied in many jurisdictions.

Conjunctive water management frameworks from around the world include significant variation in how (or if) streamflow depletion is addressed. In the USA, California's Sustainable Groundwater Management Act mandates that groundwater pumping have no unreasonable impact on interconnected surface water (Rohde et al., 2018). In Canada, British Columbia's Water Sustainability Act requires that wells do not cause reductions in streamflow beyond environmental limits (Water Sustainability Act, 2014). In the European Union, the European Water Framework Directive requires that pumping not impair environmental flows in surface 
water such as streams, though specifics on streamflow depletion estimation are not provided (Gleeson and Richter, 2018; Kallis and Butler, 2001). Australia's National Water Initiative (2004) acknowledged the interconnectivity of groundwater and surface water resources and requires conjunctive management, including explicit consideration of the impacts of impaired flows on groundwater-dependent ecosystems such as communities in groundwater-fed streams (Rohde et al., 2017; Ross, 2018).

Despite these examples, effective conjunctive management of surface water and groundwater is lagging behind scientific understanding in many settings. A review of 54 groundwater management plans in the United States found that only six (11\%) had quantitative targets related to streamflow depletion (Gage and Milman, 2020), and there are many regions around the world where streamflow depletion is not addressed by water management. For example, in India groundwater and surface water are typically managed separately (Srinivasan and Kulkarni, 2014; Harsha, 2016), and therefore "groundwater use is not considered to be linked to streamflow and is decoupled from the surface water allocation" by water management groups (Biggs et al., 2007). Even where new regulations and policies are made to address the interconnected nature of groundwater and surface water, there can be legacy effects of a different or unregulated past that adversely impact water resources (Owen et al., 2019).

The wide range of approaches to identifying, quantifying, and managing streamflow depletion around the world, as well as variable regulatory frameworks, demonstrates the need for decision resources water managers can use to select and implement appropriate streamflow depletion estimation approaches.

\section{Streamflow depletion management decisions}

We identified a number of common water management questions related to streamflow depletion (Table 1; Figure 2). Broadly, these questions can be categorized into three thematic groups:

(1) Attribution: Does pumping contribute to decreases in streamflow and, if so, how do pumping impacts compare to other drivers of change?

(2) Impacts: What are the implications of streamflow depletion for water users, ecosystems, and society?

(3) Mitigation: How can negative impacts of streamflow depletion be minimized?

Different types of information are needed to answer these questions. For answering attribution questions, it is necessary to quantify the relative importance of different potential drivers (e.g. climate, pumping, land use) on historical streamflow variation. For impact questions, useful information includes the magnitude of change in streamflow (relative to management targets and/or environmental flows) that would occur as a result of pumping from a well or group of wells. Answering mitigation questions requires understanding the impacts of 
pumping at different times of year and the magnitude and timescale of a stream's recovery following the cessation of pumping. For all of these questions, estimates are often required at different times of year and for different locations within the stream network. Furthermore, taking management action in response to these questions includes balancing the costs, benefits, and risks of a given management strategy, and therefore depletion estimates that underlie these decisions must include some information about the magnitude and sources of uncertainty (Doherty and Simmons, 2013; White, Foster, et al., 2021).

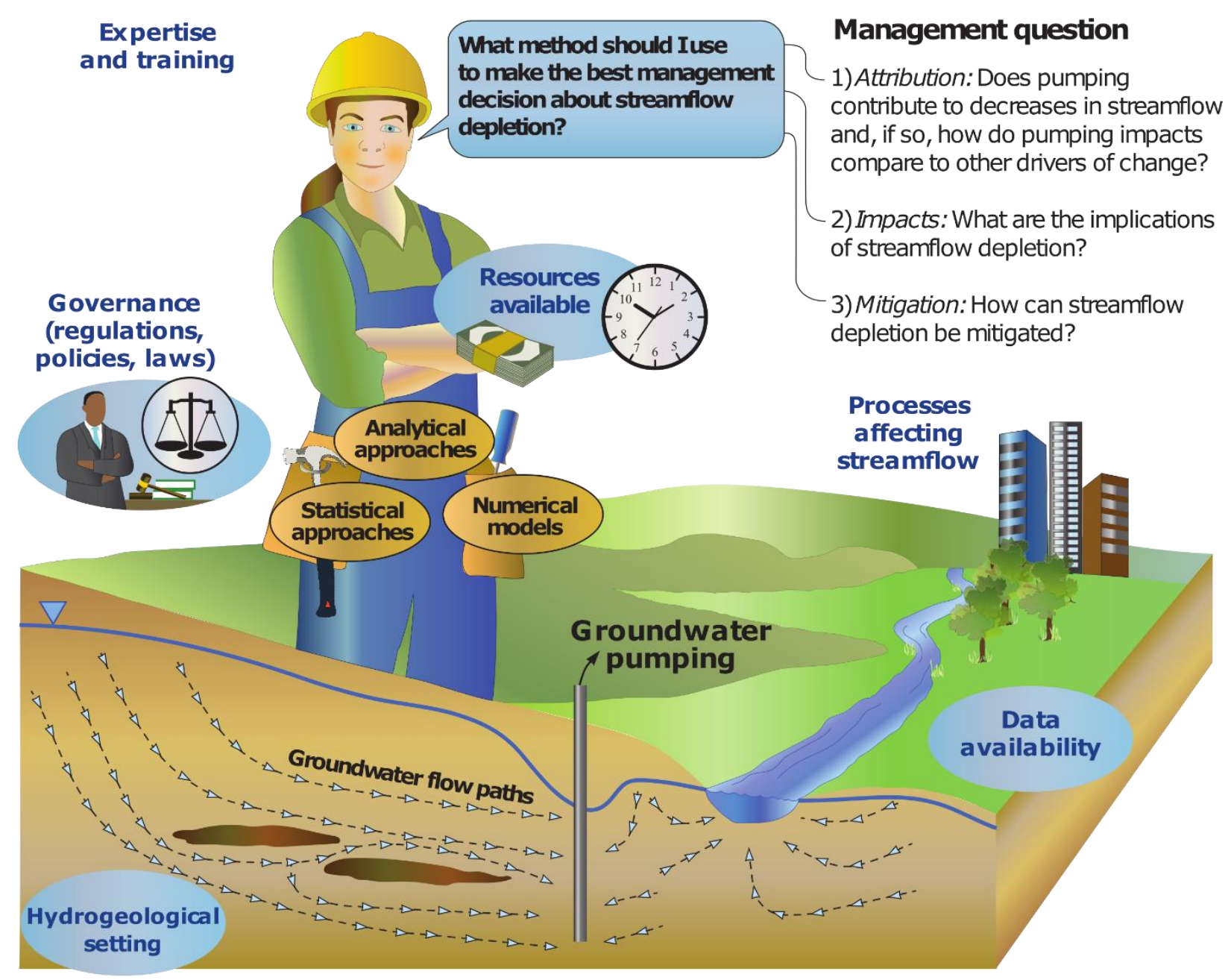

Figure 2. Factors (blue text) that may affect the decision of a streamflow depletion estimation tool, which are 
Table 1. Management questions relevant to streamflow depletion, including case studies where the example question has been addressed.

\begin{tabular}{|c|c|c|}
\hline Thematic Group & Example Question & Case Studies \\
\hline \multirow{2}{*}{$\begin{array}{l}\text { Attribution: Does } \\
\text { pumping contribute to } \\
\text { decreases in streamflow } \\
\text { and, if so, how do } \\
\text { pumping impacts } \\
\text { compare to other drivers } \\
\text { of change? }\end{array}$} & $\begin{array}{l}\text { Are irrigators responsible for the observed } \\
\text { reductions in streamflow, or is it some other factor? }\end{array}$ & $\begin{array}{l}\text { Wisconsin Central Sands } \\
\text { (Kniffin et al., 2020; Kraft et } \\
\text { al., 2012) }\end{array}$ \\
\hline & $\begin{array}{l}\text { Where and when does streamflow respond to } \\
\text { different drivers of change (climate, land use, } \\
\text { pumping)? }\end{array}$ & $\begin{array}{l}\text { Loess Plateau, China (Zhao et } \\
\text { al., 2018; Gao et al., 2016) }\end{array}$ \\
\hline \multirow{4}{*}{$\begin{array}{l}\text { Impacts: What are the } \\
\text { implications of } \\
\text { streamflow depletion (for } \\
\text { water users, ecosystems, } \\
\text { and society)? }\end{array}$} & $\begin{array}{l}\text { What are the impacts of installing a new well on } \\
\text { environmental flows? }\end{array}$ & $\begin{array}{l}\text { Michigan Water Withdrawal } \\
\text { Assessment Tool (Reeves et al., } \\
\text { 2009) }\end{array}$ \\
\hline & $\begin{array}{l}\text { Are there groundwater or surface water quality } \\
\text { repercussions associated with streamflow depletion? }\end{array}$ & $\begin{array}{l}\text { Missouri River (Kelly and } \\
\text { Rydlund, Jr., 2006) }\end{array}$ \\
\hline & $\begin{array}{l}\text { Would a new well impact senior water rights, } \\
\text { critical habitat, and/or environmental flows? }\end{array}$ & $\begin{array}{l}\text { British Columbia Water } \\
\text { Sustainability Act (Water } \\
\text { Sustainability Act, 2014) }\end{array}$ \\
\hline & $\begin{array}{l}\text { How long does it take to detect streamflow depletion } \\
\text { and are we seeing the full impacts of pumping now? }\end{array}$ & Australia (Evans et al., 2006) \\
\hline \multirow{4}{*}{$\begin{array}{l}\text { Mitigation: How can } \\
\text { negative impacts of } \\
\text { streamflow depletion be } \\
\text { minimized? }\end{array}$} & $\begin{array}{l}\text { Would a proposed pumping reduction and } \\
\text { streamflow augmentation plan meet in-stream flow } \\
\text { requirements? }\end{array}$ & $\begin{array}{l}\text { Quivira National Wildlife } \\
\text { Refuge (KDA-DWR, 2019) }\end{array}$ \\
\hline & $\begin{array}{l}\text { What management actions are needed to avoid } \\
\text { unreasonable impacts of pumping on interconnected } \\
\text { surface waters? }\end{array}$ & $\begin{array}{l}\text { California Groundwater } \\
\text { Sustainability Agencies (Owen } \\
\text { et al., 2019; Rohde et al., 2018) }\end{array}$ \\
\hline & $\begin{array}{l}\text { Can streamflow depletion impacts be addressed by } \\
\text { modifying the timing and/or location of groundwater } \\
\text { withdrawals? }\end{array}$ & $\begin{array}{l}\text { Gallatin River, Montana } \\
\text { (Kendy and Bredehoeft, 2006) }\end{array}$ \\
\hline & $\begin{array}{l}\text { Can managed aquifer recharge mitigate against } \\
\text { streamflow depletion impacts? In which regions } \\
\text { could managed aquifer recharge provide the most } \\
\text { benefit? }\end{array}$ & $\begin{array}{l}\text { Nam River, South Korea (Lee } \\
\text { et al., 2019); Eastern Snake } \\
\text { Plain Aquifer, Idaho (Idaho } \\
\text { Water Resource Board, 2019) }\end{array}$ \\
\hline
\end{tabular}


Many factors contribute to water management decisions (Figure 2). Based on literature review and our experience, we suggest four general characteristics that are essential to providing decision support for streamflow depletion management. The first two characteristics can help guide the selection of an appropriate method:

(1) Well-suited to local conditions. In order to isolate the signal of pumping, the streamflow depletion estimation method should be able to account for other potential influences on streamflow, and associated uncertainty, within the domain of interest (e.g., Knowling et al., 2020). Depending on the region, these may include weather and climate variability, land use change, surface water withdrawals, reservoir operations, or other ways that humans modify the water cycle (Abbott et al., 2019; Gleeson, Wang-Erlandsson, et al., 2020). Local expert knowledge, in the form of a place-based understanding of processes that are currently and have historically affected local hydrology, is essential to identify the potential influences on streamflow that need to be considered by a streamflow depletion estimation approach, and because depletion management policies are increasingly implemented at local scales (Opdam et al., 2013).

(2) Actionable. For management purposes, the method must be able to provide an estimate within an acceptable margin of error with input data that either already exist and/or can be obtained, and provide sufficient information about prediction uncertainty so that a water manager can weigh costs, benefits, and risks of their decision options (Doherty and Simmons, 2013; Fienen et al., 2021). Implicit within actionability are numerous practical considerations, including whether there is sufficient in-house expertise to implement the method or whether analysis must be contracted, and the related issue of whether the cost of obtaining streamflow depletion estimates is affordable.

The third and fourth characteristics are good scientific practices to enhance stakeholder trust and engagement regardless of the specific streamflow depletion estimation method used.

(3) Transparent. The logic behind the choice of the method should be communicated to relevant stakeholders who will be affected by the streamflow depletion estimates including the strengths, weaknesses, assumptions, and uncertainties of the chosen approach and any alternatives (Eker et al., 2018). Ideally, the study design would incorporate stakeholders because co-development of methods and scenarios enhances stakeholder understanding of, and trust in, the resulting streamflow depletion estimates (Kniffin et al., 2020), increases the perceived legitimacy of research (Dickert and Sugarman, 2005), and can improve the quality of decisions (Reed, 2008). Further, uncertainty and sensitivity analyses are necessary to evaluate the overall uncertainty in estimates and relative importance of different input parameters, respectively (Pianosi et al., 2016; Saltelli et al., 2019). 
(4) Reproducible. Ensuring that the analysis and results can be reproduced is essential to enhancing trust in streamflow depletion estimates and addressing potential legal challenges to official decisions (Munafò et al., 2017). Necessary steps to ensure reproducibility would likely include archiving raw and processed data files, model input files, calibration datasets, and code necessary to run any analyses or models and version used (Lowndes et al., 2017; Wilkinson et al., 2016). While there have been substantial recent improvements in open-source tools to enable reproducible hydrological modeling workflows (Bakker et al., 2016; Fienen et al., 2021; White, Hemmings, et al., 2021), in practice true reproducibility remains rare in hydrological science (Stagge et al., 2019), indicating that significant improvements are needed with regards to reproducibility. However, in some settings, in particular at smaller spatial scales where there are fewer pumping wells, care should be taken to ensure that individual privacy is not compromised during data sharing by anonymizing or aggregating data to coarser scales (Zipper, Carah, et al., 2019; Zipper, Stack Whitney, et al., 2019).

\section{METHODS USED FOR QUANTIFYING STREAMFLOW DEPLETION}

In this section, we describe strengths and weaknesses of analytical, numerical, and statistical approaches to estimate streamflow depletion (Table 2), and provide examples of where each method has been used for making water management decisions related to streamflow

257 depletion.

258 Table 2. Strengths, weaknesses, and considerations with respect to decision criteria.

\begin{tabular}{|c|c|c|c|}
\hline Method & Strengths & Weaknesses & $\begin{array}{l}\text { Considerations with respect to } \\
\text { criteria }\end{array}$ \\
\hline $\begin{array}{l}\text { Analytical } \\
\text { models }\end{array}$ & $\begin{array}{l}\text { - Low data, expertise, and } \\
\text { computational } \\
\text { requirements } \\
\text { - Can quickly explore } \\
\text { different pumping } \\
\text { scenarios } \\
\text { - Useful as a screening tool } \\
\text { to prioritize further } \\
\text { investigation with other } \\
\text { approaches } \\
\text { - Long history in water } \\
\text { management applications }\end{array}$ & $\begin{array}{l}\text { Many simplifying } \\
\text { assumptions (constant } \\
\text { stream water level, } \\
\text { homogeneous subsurface, } \\
\text { etc.) } \\
\text { - Limited capability for } \\
\text { scenario analysis due to } \\
\text { inability to represent many } \\
\text { processes } \\
\text { (evapotranspiration, } \\
\text { unsaturated flow) } \\
\text { - Derivations are not } \\
\text { available for many stream- } \\
\text { aquifer systems } \\
\text { - Limited spatial extent } \\
\text { (point based predictions) }\end{array}$ & $\begin{array}{l}\text { Well-suited: Simplifying } \\
\text { assumptions often preclude } \\
\text { models that include important } \\
\text { site-specific processes. } \\
\text { - Actionable: Low data and } \\
\text { expertise requirements to } \\
\text { implement; many spreadsheet } \\
\text { tools exist. } \\
\text { - Transparent: Simplified model } \\
\text { form is often easy to explain. } \\
\text { Can provide sensitivity analysis, } \\
\text { but limited framework for } \\
\text { uncertainty analysis. } \\
\text { - Reproducible: Simplified model } \\
\text { forms are often easier to share } \\
\text { and reproduce. }\end{array}$ \\
\hline $\begin{array}{l}\text { Numerical } \\
\text { models }\end{array}$ & $\begin{array}{l}\text { - Realistic representation of } \\
\text { many processes in up to } 3 \\
\text { spatial dimensions plus }\end{array}$ & $\begin{array}{l}\text { - High data, expertise, time } \\
\text { required } \\
\text { - Can be large }\end{array}$ & $\begin{array}{l}\text { - Well-suited: Most potentially } \\
\text { important processes can be } \\
\text { included, and uncertainty }\end{array}$ \\
\hline
\end{tabular}




\begin{tabular}{|c|c|c|c|}
\hline & $\begin{array}{l}\text { time } \\
\text { Ability to assign/test } \\
\text { causation and explore } \\
\text { different scenarios } \\
\text { - Provide solutions for both } \\
\text { storage and flux } \\
\text { Widely used and } \\
\text { perceived as accurate for } \\
\text { streamflow depletion } \\
\text { calculations } \\
\text { Estimating uncertainties } \\
\text { in parameters and } \\
\text { predictions is possible } \\
\text { Predictions outside } \\
\text { training conditions are } \\
\text { limited by the physics } \\
\text { represented by the model, } \\
\text { which can make the } \\
\text { predictions more reliable }\end{array}$ & $\begin{array}{l}\text { computational costs } \\
\text { Challenging to test due to } \\
\text { common data limitations } \\
\text { - Predictions outside } \\
\text { training conditions may } \\
\text { not be reliable (but maybe } \\
\text { better than other } \\
\text { approaches?) } \\
\text { Mass balance numerical } \\
\text { errors can overwhelm } \\
\text { pumping signal } \\
\text { Can appear realistic even } \\
\text { when errors are large }\end{array}$ & $\begin{array}{l}\text { associated with different } \\
\text { processes and inputs can be } \\
\text { quantified. } \\
\text { Actionable: Specialized, model- } \\
\text { specific training is required for } \\
\text { development and use. Some } \\
\text { models have legal standing, } \\
\text { making results actionable. } \\
\text { Transparent: Sensitivity and } \\
\text { uncertainty analyses are } \\
\text { possible but computationally } \\
\text { expensive } \\
\text { Reproducible: Many open- } \\
\text { source tools facilitate } \\
\text { reproducibility, though some } \\
\text { numerical models are } \\
\text { proprietary. }\end{array}$ \\
\hline $\begin{array}{l}\text { Statistical } \\
\text { models }\end{array}$ & $\begin{array}{l}\text { - } \begin{array}{l}\text { Flexible framework } \\
\text { adaptable to a wide range } \\
\text { of information sources } \\
\text { and target metrics }\end{array} \\
\text { - } \begin{array}{l}\text { Do not require hard-to- } \\
\text { collect data about } \\
\text { subsurface }\end{array} \\
\text { Generally lower } \\
\text { computational needs and } \\
\text { less domain-specific } \\
\text { expertise is required } \\
\text { compared to numerical } \\
\text { models } \\
\text { Work well for the analysis } \\
\text { and simulation of long } \\
\text { records }\end{array}$ & $\begin{array}{l}\text { Challenging to develop } \\
\text { causal attribution } \\
\text { May not provide level of } \\
\text { detail/resolution in terms } \\
\text { of space and time needed } \\
\text { to test some hypotheses or } \\
\text { evaluate management } \\
\text { questions. } \\
\text { Often narrow focus; } \\
\text { designed around specific } \\
\text { objectives with challenges } \\
\text { moving outside of that } \\
\text { objective } \\
\text { Predictions outside } \\
\text { training conditions may } \\
\text { not be reliable } \\
\text { Often need large datasets } \\
\text { for training }\end{array}$ & $\begin{array}{l}\text { Well-suited: Accuracy and } \\
\text { ability to represent local } \\
\text { processes are highly dependent } \\
\text { on observed data to represent } \\
\text { similar conditions. } \\
\text { - Actionable: Flexible approach } \\
\text { can leverage diverse data } \\
\text { sources depending on local } \\
\text { availability. } \\
\text { Transparent: Many model forms } \\
\text { are easily understood, though } \\
\text { some are considered "black } \\
\text { box". Model parameters often } \\
\text { do not have physical meaning } \\
\text { related to field conditions. } \\
\text { Reproducible: Stochastic } \\
\text { models and models relying on } \\
\text { underlying randomness can be } \\
\text { difficult to reproduce. }\end{array}$ \\
\hline
\end{tabular}

261 Overview. Analytical models were the first tool developed for streamflow depletion estimation,

262 and have been used for almost 80 years in many regulatory and other resource management

263 circumstances (Glover and Balmer, 1954; Hantush, 1965; Jenkins, 1968; Theis, 1941).

264 Analytical models adopt a number of assumptions to simplify stream-aquifer interactions and 
estimate streamflow depletion based on governing equations for groundwater flow and the conservation of mass (Barlow and Leake, 2012). They typically provide streamflow depletion estimates caused by a single well in a single stream, though estimates of depletion are often combined additively to account for impacts of multiple wells.

Strengths. The primary strengths of analytical models are their relatively low data requirements and their ease of use (Table 2). For example, the only inputs required by the widely used model of Glover and Balmer (1954) are aquifer transmissivity, storativity, and the distance from the well to the stream. The more complex Hunt (1999) model requires only a single additional term, the streambed conductance, to account for a potential low-permeability streambed layer, though distributed regional-scale estimates of streambed conductance are challenging to measure and rarely available (Christensen, 2000; Abimbola et al., 2020; Korus et al., 2018, 2020). Spreadsheet tools are available online to calculate streamflow depletion with a variety of analytical models (e.g., Environment Canterbury, 2020). Since calculations can be conducted rapidly, they are well-suited for integration into web-based decision support tools and can provide screening estimates to prioritize more detailed study (Huggins et al., 2018). Furthermore, these low computational costs enable rapid and straightforward sensitivity and uncertainty analysis of depletion results, though these assessments are inherently limited by the assumptions required to develop analytical models (see 'Weaknesses' subsection).

Weaknesses. The primary weakness of analytical models is in the required number of simplifying assumptions to derive analytical solutions. Common assumptions include a homogeneous and isotropic subsurface, linear streams, and constant water levels in the stream and aquifer through time. These assumptions limit the ability of analytical models to represent important processes, such as changes phreatophytic evapotranspiration caused by pumping, and the possible scope of uncertainty analysis, since the impact of many uncertain processes and parameters cannot be evaluated due to the limited input requirements and simple model structure of analytical models (Table 2). Analytical models have been derived for many different, though still idealized, hydrogeological settings, including wedge-shaped aquifers at the confluence of two streams (Yeh et al., 2008), streams that intersect impermeable boundaries (Singh, 2009), partially-penetrating streams (Hunt, 2003; Hunt et al., 2001), leaky aquifers (Butler et al., 2007; Zlotnik and Tartakovsky, 2008), variable streambed conductivity (Neupauer et al., 2021), and impacts of land use change (Traylor and Zlotnik, 2016; Zlotnik, 2015). Huang et al., (2018) review the large number of existing analytical models and present a guide for analytical model selection based on aquifer and stream characteristics.

Emerging Approaches. Recently, analytical depletion functions were proposed as an empirical tool to overcome the assumptions of a linear stream by accounting for multiple affected stream reaches and stream sinuosity (Zipper, Dallemagne, et al., 2018; Zipper, Gleeson, et al., 2019, 2021; Li et al., 2020, 2021). Analytical depletion functions combine (1) an analytical model with stream proximity criteria, which is used to identify stream segments that are potentially affected by a well, and (2) a depletion apportionment equation, which then distributes the estimated 
streamflow depletion among the stream segments (Zipper, Gleeson, et al., 2019). In inter-model comparisons, the analytical depletion functions had a better agreement with process-based numerical models than standalone analytical models (Zipper, Gleeson, et al., 2019, 2021), potentially indicating improved accuracy of spatially-distributed estimates of streamflow depletion. Despite these improvements, analytical depletion functions are subject to most of the same assumptions as analytical models, and therefore require additional testing before widespread use.

311 Example Use in Management. Due to their relatively long history and ease of implementation, analytical models have been used for water management in a number of settings. In Colorado and other jurisdictions in the western United States, the streamflow depletion factor has been used to characterize streamflow depletion and establish regulatory guidelines for streamflow depletion by wells for streams that have senior rights holders (Miller et al., 2007). The streamflow depletion factor (SDF) was defined by Jenkins (1968) from an analytical solution (Glover and Balmer, 1954) as the time required for the streamflow depletion to equal 28 percent of the volume pumped from the well. The SDF is estimated using the distance from the well to the stream and the effective storativity and transmissivity of the aquifer. In some applications the analytical solution itself is reduced to consideration of the SDF to account for the potential time lag between the initiation of pumping and impact on a stream, or, conversely, for the required time lag for the streamflow to recover once pumping is stopped. Use of the SDF is convenient because this factor can be mapped (for example, Jenkins and Taylor, 1972) to support communication and management, and therefore provide a rapid tool for water managers to evaluate the relative magnitude and timing to impact of wells placed in different locations. Furthermore, in settings where response functions such as the SDF have been well-characterized and reliable groundwater withdrawal data are available, water use accounting can provide reasonable estimates of the attribution and impacts of streamflow depletion, as well as evaluate mitigation strategies.

Another example is the State of Michigan's Water Withdrawal Assessment Tool apportionment equation to estimate potential impacts of groundwater pumping on surface water resources (Reeves et al., 2009). This tool is used to screen high-capacity well registration for the state using risk-based streamflow depletion criteria (Ruswick et al., 2010; Steinman et al., 2011). In the eleven years since use of the tool became part of the registration process, nearly 3,400 registrations were completed by passing the screening criteria. An additional 1,500 registrations did not initially pass the screening and were referred to the state for site specific review where all but 60 were allowed to register after additional analysis (Michigan Water Use Advisory Council, 2020). 
341 Overview. In contrast to analytical models, numerical models typically include a threedimensional representation of the surface and subsurface and solve for storage and flow throughout the domain. Typically, models are developed for a region of interest (such as an aquifer or a watershed), a process that includes considerable data collection, data base management, model construction, history matching, and visualization. Streamflow depletion is estimated by comparing flow in surface water features in simulations with and without pumping in all or a subset of the domain (Ahlfeld et al., 2016; Hill et al., 1992; Neupauer and Griebling, 2012; Zipper, Gleeson, et al., 2021). Most streamflow depletion studies based on numerical models have used groundwater flow models such as MODFLOW, but recent examples have included integrated hydrologic models that couple land surface, vadose zone, and groundwater processes to simulate feedbacks between pumping, groundwater recharge, subsurface storage, and streamflow (Condon and Maxwell, 2014, 2019; Woolfenden and Nishikawa, 2014; Kollet et al., 2017). Numerical models for streamflow depletion estimation can be created at a variety of scales, ranging from an individual watershed or aquifer (Kniffin et al., 2020; Leaf et al., 2015; Tolley et al., 2019), to regions (Rossman and Zlotnik, 2013), to continental or global (Condon and Maxwell, 2019; de Graaf et al., 2019; Liu et al., 2019).

Strengths. Numerical models are typically considered the 'gold standard' of streamflow depletion assessment because they can evaluate the impacts of multiple scenarios caused by simultaneous changes in pumping, climate and land cover, be more readily tested via comparison to field data, and provide a rigorous framework for causation and uncertainty analysis (Hill and Tiedeman, 2007; Barlow and Leake, 2012; Knowling et al., 2019). As a result, numerical models are widely used management tools. As numerical models are based on the physical representation of hydrological processes and simulate both the storage and flux of water throughout the groundwater and interconnected surface water system, they are more flexible than analytical models. Processes such as vadose zone dynamics, phreatophytic evapotranspiration, and surface water management can be directly included within a numerical modeling framework to estimate their separate or combined impact on streamflow (Brookfield and Gnau, 2016; Condon and Maxwell, 2013; Markstrom et al., 2008; Tolley et al., 2019; Zipper et al., 2017), and data associated with each of these processes can be assimilated into the model during the history matching process (Camporese et al., 2010; Naz et al., 2019; Fienen et al., 2021).

Numerical models are typically discretized into grid cells or elements that cover the domain or interest so that each of these hydrological processes can be simulated in three spatial dimensions and through time. This process-based representation allows for explicit testing and evaluation of causal mechanisms because (for example) the effects of a pumping well on groundwater storage, streamflow depletion, evapotranspiration, and recharge can be estimated. In addition, the process-based representation allows users to estimate model uncertainty and identify key parameters and processes that contribute to uncertainty (Knowling et al., 2019, 2020; Ferré, 2017). Since management decisions require evaluating costs, benefits, and risks, 
numerical models subjected to thorough uncertainty analysis can allow water managers to discriminate among competing conceptual models, reduce uncertainty through the collection of additional data, and assess the risk of undesirable outcomes (Leaf, 2017; Enemark et al., 2019;

382 Ferré, 2017).

Weaknesses. Numerical models' complexity relative to the other approaches also introduces several limitations related to the data, computational, and human resources needed to develop numerical models appropriate for streamflow depletion assessment. Numerical models require hydrostratigraphic data at all grid cells or nodes (which can number from thousands to hundreds of thousands or even millions), as well as appropriate parametrization for any other processes included in the simulations such as streambed properties or evapotranspiration. This requires substantial user input and expertise, including the need to make numerous subjective decisions about the processes included and how they are represented, which has been referred to as "the art of environmental simulation" and is developed through training and experience (Doherty and Simmons, 2013). Often, limited field observations mean that these values are estimated from a small number of locations and extrapolated widely across the domain and/or derived from lookup tables, though ever-increasing availability of local, regional, and global-scale hydrometeorological and hydrogeological data is helping to address this challenge. Nonetheless, the high data needs relative to data availability in many settings can mean that stakeholders whose water use is affected by the outputs of the model may be concerned that the numerical model does not accurately reflect their particular context (e.g., Wardropper et al., 2017).

For a numerical model to be confidently used in streamflow depletion assessment, history matching should be performed to ensure that simulated baseflow and hydraulic head agree with observations at numerous points within the domain and for a range of different pumping conditions (Hill, 2006; Hill and Tiedeman, 2006). Given the highly parameterized nature of numerical models and the fact that models can never exactly characterize the hydrologic system, they are typically non-unique, meaning that many different parameter combinations can provide equally good agreement with observations and can lead to uncertainty when testing scenarios outside the model calibration conditions (sometimes referred to as the 'equifinality hypothesis'; Beven, 2006; Hunt et al., 2020; Konikow \& Bredehoeft, 1992). This has precipitated a recent shift in the discipline towards ensemble-based model development that seeks to connect uncertainty between model inputs and outputs (e.g., Foster et al., 2021; White, Hemmings, et al., 2021), rather than calibration-focused strategies that seek to identify a single set of "correct" parameter values. However, calibration-focused strategies continue to be widespread and models developed in the past using these strategies continue to be used, and can lead to a false sense of accuracy in contexts with equifinality because the model can match historical data well and appear highly realistic even if processes and parameters are incorrect (Doherty and Moore, 2020). Adopting a 'forecast first' workflow, where scenario forecasting efforts are iteratively integrated with model development and calibration (White, 2017), can be valuable as they allow model creators to determine whether additional model complexity and calibration provide 
improved forecasts, thus ensuring that forecasts provide acceptable uncertainty for decisionmakers to assess risk of undesirable outcomes relative to costs and benefits of a management action (Doherty and Simmons, 2013).

Furthermore, increasing data availability is enabling calibration methods based on numerous targets such as groundwater head, evapotranspiration, and land surface temperature to provide a more robust approach for streamflow and groundwater head prediction compared to calibration based on head and discharge alone (Stisen et al., 2018). For example, Hunt et al. (2020) found that including both hydraulic head and fluxes in model development substantially improved history matching and forecasting capabilities compared to using hydraulic head alone, and that multi-variate or multi-objective model calibration approaches can reduce overfitting even in highly parameterized models when the practitioner has sufficient deep knowledge and expertise to implement appropriate parameter regularization techniques (see also Moore and Doherty, 2006). The use of multiple evaluation datasets are becoming more prevalent with the widespread use of integrated hydrologic models and the increasing amount of hydrological data (Schreiner-McGraw and Ajami, 2020).

The ability to capture depletion dynamics depends heavily on the temporal and spatial resolution of the model. While a more refined grid provides greater detail on depletion dynamics, it can increase computational demand, potentially making simulations infeasible. Numerical models rely on the convergence of the flow solution to within some user-defined head threshold, which means that regional-scale numerical models are often poorly suited for estimating the impacts of an individual well, particularly in large domains, because they cannot estimate depletion that is less than the model's mass balance error (Leake et al., 2010). This further reinforces the point that decision support models should be specifically designed for the management action under consideration, rather than developing a single model for a region that is then used to answer a variety of different management questions (Doherty and Moore, 2020).

Finally, some numerical modeling platforms (i.e., HydroGeoSphere, FEFLOW, COMSOL) are proprietary, which limits transparency and reproducibility of any analysis done using these platforms by other users. The most widely used numerical modeling platform (MODFLOW) as well as many emerging approaches (i.e., GSFLOW, ParFlow) are open source and are well-suited for streamflow depletion in decision making. There are also many emerging open-source tools for the reproducible creation and analysis of numerical models (Bakker et al., 2016; Fienen et al., 2021; Gardner et al., 2018; Ng et al., 2018; White et al., 2016, 2018, 2021).

Emerging Approaches. Numerical models continue to evolve as computational resources, data, and understanding of hydrologic systems advance. Relevant to managing streamflow depletion, integrated hydrologic models that capture flow and transport dynamics across the hydrologic cycle are increasingly incorporating anthropogenic activities, such as groundwater pumping, surface water diversions, reservoir management, and economic factors (Boyce et al., 2020; Brookfield et al., 2017; Morway et al., 2016; Niswonger et al, 2017; Rouhi 
Rad et al., 2020). Some of these models incorporate water operational rules and constraints, thereby integrating water management decision-making into numerical models (Brookfield et al., 2017; Brookfield and Gnau, 2016; Morway et al., 2016). This integration allows the co-evolution of hydrological, ecological, management, and societal conditions, rather than dependence on static boundary conditions and sources/sinks (Konar et al., 2019; O'Keeffe et al., 2018; Srinivasan et al., 2017). Examples include the Agricultural Water Use package for MODFLOW and GSFLOW, which can be used to estimate agricultural water use and resulting streamflow depletion impacts (Niswonger, 2020); the MODFLOW Farm process (Schmid and Hanson, 2009); incorporation of a water allocation module into an integrated hydrologic model, ParFlowCLM (Condon and Maxwell, 2013); inclusion of surface water operations and surface water and groundwater extraction in HydroGeoSphere (Brookfield et al., 2017; Hwang et al., 2019); Spain's AQUATOOL decision support system which couples water allocation, quantity, quality, and routing (Paredes-Arquiola et al., 2010; Pedro-Monzonis et al., 2016); and coupling of MODFLOW with the reservoir-operations model MODSIM (Morway et al., 2016).

Hydrologic models are also integrating and improving upon vegetation dynamics, allowing the models to better predict water demand and crop yields, which drive irrigation, in future climate and policy scenarios. For example, integration of crop growth and irrigation modules in the Variable Infiltration Capacity model (VIC-CropSyst) improved hydrologic simulations in agricultural watersheds (Malek et al., 2017). HydroGeoSphere recently incorporated on-demand irrigation into their modeling framework, which triggers groundwater extraction during the user-defined growing season when the pressure head at a specified location and depth declines below a prescribed level. Coupling of the widely used Soil Water Assessment tool (SWAT) with MODFLOW and groundwater solute reactive transport model RT3D (SWATMODFLOW-RT3D) has increased broader applicability of the model in regions with conjunctive water use or groundwater contamination (Wei et al., 2019).

Since complexity is one of the primary challenges for numerical model development and use, several promising emerging approaches seek to balance the advantages of improved process representation in numerical models while minimizing model complexity and runtime. For example, surrogate models are simplified models focused on the dominant features of a groundwater problem of interest to allow for more robust sensitivity analysis and scenario exploration than numerical models (Asher et al., 2015; Razavi et al., 2012). Hierarchical approaches to surrogate modeling exclude some processes and therefore have a faster model runtime while maintaining a high level of accuracy. For instance, in streamflow depletion studies it may be acceptable to simplify the representation of unsaturated zone processes, which can have substantial computational costs, if pumping is not expected to substantially change groundwater recharge. Data-driven approaches to surrogate modeling, also referred to as "metamodeling", train statistical models on the input and output data from numerical models so the simpler statistical model is used for scenario assessment. Metamodels have recently emerged in the groundwater community and can be incorporated into decision support systems for 
streamflow depletion scenario analysis (Fienen et al., 2015, 2016; Fienen, Nolan, et al., 2018; Starn and Belitz, 2018). However, both of these surrogate modeling approaches are still only feasible in locations where numerical models already exist for surrogate model training. Spreadsheet-based approaches provide a simplified interface for creating and developing finitedifference numerical models with a lower data and expertise requirements while still retaining strong process representation that allows for examination of multiple processes simultaneously (Robinson, 2020), and therefore provide a promising intermediate-complexity approach between numerical and analytical models.

503 Example Use in Management. Numerical models have been used to estimate streamflow depletion in many settings around the world. One well-known example is the Republican River Compact Administration groundwater model (RRCA, 2003), which is a MODFLOW model used to make water allocation decisions among the states of Colorado, Nebraska, and Kansas. The original 1943 Republican River Compact allocated the distribution of water among subbasins in each of the three states, but did not explicitly address how to account for streamflow depletion caused by groundwater pumping. Following a U.S. Supreme Court settlement between Kansas, Nebraska and Colorado, the interstate compact was modified to account for streamflow depletion due to groundwater extraction, which is quantified using the groundwater flow model jointly developed by the three states and federal government (RRCA, 2003; Zipper, Gleeson, et al., 2021). Each year, the states submit estimates of water supply and use, jointly evaluate the results of water accounting, update the MODFLOW model to estimate groundwater consumptive use and streamflow depletion across the basin, and assess compliance with the terms of the

\section{$517 \quad$ Statistical assessments and models}

518 Overview. In contrast to analytical and numerical models, both of which model physical 519 processes using governing equations of water flow, statistical approaches rely on interpolations, extrapolations, and relationships among observed data to characterize hydrologic states and fluxes. These statistical approaches are based on physical hydrological processes through the selection of relevant variables or model structures that have the potential to reflect key processes influencing streamflow. Therefore, adopting a statistical approach does not lead to the exclusion of physical process understanding, but merely means that relationships among variables are not necessarily controlled by governing equations such as Darcy's Law. There are numerous statistical approaches that have been used or are relevant to streamflow depletion assessment, and we adopt a broad definition to include emerging data-driven approaches such as machine learning within our discussion. Here, we distinguish between statistical assessments, which analyze hydrologic variables (e.g., trend analysis), and statistical models, which estimate hydrological variables (e.g., regression analysis).

Statistical assessments of streamflow depletion typically quantify changes or trends in streamflow or baseflow as well as changes or trends in potential drivers such as groundwater 
pumping and precipitation, and relate the two. For example, Kustu et al. (2010) observed a spatial match between negative trends in groundwater levels and streamflow across the U.S. High Plains Aquifer and inferred a connection between the two based on the absence of potential explanatory precipitation trends, and Juracek (2015) compared numerous gages in southern Kansas and found significant decreasing streamflow trends in basins with the greatest groundwater level decline and a lack of precipitation trends, which together suggested that streamflow depletion was the cause of observed streamflow trends. In Brazil, Lucas et al. (2021) suggested streamflow depletion was leading to a decline in baseflow due to a spatial agreement between declining baseflow trends, increasing evapotranspiration trends, and irrigated agricultural land. In contrast to statistical assessments, statistical models applied to streamflow depletion estimation typically attempt to quantify some relationship between groundwater pumping and long-term changes in streamflow and/or baseflow, often as one of several predictors. For instance, Holtschlag (2019) included irrigation in linear mixed models of summer water yield for many watersheds in Michigan, allowing them to determine whether it was an important predictor of streamflow; similar approaches have been used elsewhere (Burt et al., 2002; Prudic et al., 2006). Broadly, statistical assessments can identify potential drivers of streamflow depletion, and the links identified through assessment can then be represented and tested using more detailed approaches such as analytical, statistical, or numerical models.

Given the widespread availability of streamflow and meteorological data relative to groundwater data, there are numerous large-scale statistical assessments documenting trends in hydrological signatures that may be relevant to streamflow depletion. For example, Ayers et al. (2019) calculated monthly baseflow trends across the mid-western United States and found significant negative trends in areas with widespread groundwater pumping such as western Kansas and Nebraska. However, in practice, statistical models are rarely used for streamflow depletion management, largely due to an inability to assess causal relationships and responses to management actions. However, the emerging data-driven statistical approaches discussed below are promising potential tools that may improve our ability to quantify, predict and evaluate streamflow depletion.

\section{Strengths. Statistical assessments and models are diverse and have their own, individual} strengths and weaknesses. However, we can generalize several common strengths relative to analytical and numerical models. In many other areas of hydrology, statistical approaches are popular for their ease of application and low data requirements (Farmer et al., 2014). While these approaches have not been widely used for the assessment of impacts and mitigation strategies in the field of streamflow depletion, they have some characteristics that may make them well-suited to these tasks. Statistical approaches tend to be adaptable to a wide range of potential data types and availabilities, making them flexible across different domains. Statistical approaches may be particularly useful in settings where subsurface hydrostratigraphic data, which are critical to accurate analytical and numerical model development but are not essential to statistical models, are unavailable. Similarly, statistical approaches are flexible to a wide range of target metrics; for 
example, statistical assessment and models can be used on any hydrological signature derived from a hydrograph (McMillan, 2020), and therefore could effectively represent various aspects of the local hydrological response to pumping. This information is particularly valuable where there may be specific flow conditions or metrics with high relevance to either management or ecological outcomes (Yarnell et al., 2020), as the statistical models can be developed to prioritize performance for predictions most relevant to needed management decisions.

Additionally, statistical approaches generally have lower computational requirements than numerical models, though for some data-intensive applications statistical model training can be computationally demanding. This means that they are well-suited for conducting large numbers of simulations necessary for accurate calibration, sensitivity and uncertainty analysis, and to develop probabilistic estimates. Statistical models are capable of quantifying uncertainty in hydrological predictions and the underlying parameters and processes that contribute to uncertainty (Fang et al., 2020; Pathiraja et al., 2018; Piazzi et al., 2021), though this type of analysis has not been done (to our knowledge) in a streamflow depletion context to date.

Weaknesses. Statistical approaches have been widely used to quantify hydrologic states and fluxes, but have rarely been used to quantify streamflow depletion (Barlow and Leake, 2012). This is largely because streamflow depletion is damped and lagged relative to groundwater pumping due to the diffusivity of the groundwater system and distance of a stream from the point of withdrawal, and further obscured by natural hydrometeorological variability and other human activities that affect streamflow (i.e., land use change, reservoir operations), making statistical quantification of the direct causal link between pumping and streamflow change hard to detect. Statistical approaches are particularly challenging in settings where hydrologic data are not available prior to the onset of groundwater pumping, and where long-term groundwater pumping data are not available. To fill these gaps, developing relationships with proxies for groundwater use -- such as crop evapotranspiration derived from remote sensing (Foster et al., 2019) -- may be necessary for the wide application of statistical models to approximate streamflow depletion, though care should be taken to account for potential errors and uncertainty in proxy datasets (Foster et al., 2020). In settings where causal attribution is impossible, statistical assessments can detect locations of potential streamflow depletion and infer potential drivers based on system understanding and available evidence (Prudic et al., 2006; Wahl and Tortorelli, 1997; Penny et al., 2020), but additional methods (such as numerical models) would be needed to explicitly develop causal links between groundwater pumping and changes in baseflow or streamflow that are needed for evaluating attribution, impacts, and mitigation decisions.

While statistical approaches are highly flexible, they are constrained by the available data and the conditions represented by that data. The ability of a statistical model to represent the needed level of detail or at the required resolution of space and time is dependent on the availability of appropriate data to characterize the objectives at the required detail and resolution. Statistical models, also called data-driven models, are often limited in scope because they rely on 
610 available data for a specific objective. The objective may, of course, be far reaching, and the 611 statistical model will require appropriate data to learn from.

Just as numerical and analytical models are calibrated to specific objectives, statistical models are designed around specific objectives. Unlike numerical and analytical models, statistical models often lack the explicit representation of processes that support extrapolations beyond the model's original design. For example, a numerical model may be designed to estimate streamflow depletion at a particular stream gage and calibrated to reproduce this value accurately; in doing so, as a product of its process representation, this model may also produce by-products like estimated groundwater storage. A statistical model with the same calibration target may achieve similar accuracy, but may not produce other targets not specified in the objective function. However, like numerical models, uncertainty analysis of statistical models can be used to quantify uncertainty associated with forecasts outside of training conditions and identify the major contributors to that uncertainty. In many cases, uncertainty-centered workflows developed for numerical models, such as the 'forecast first' workflow to modeling discussed in the 'Numerical Models' section above (White, 2017), could be directly adapted to integrate into statistical modeling workflows.

Emerging Approaches. Determining causality between groundwater pumping and streamflow depletion is challenging with traditional statistical regression models and is a primary reason that they have not been used extensively in streamflow depletion assessments. Randomized controlled experiments used to identify causal relationships are often impractical, if not impossible, in hydrology (Ombadi et al., 2020; Runge et al., 2019). However, the ever-growing amount of observational data from sources such as stream gages, climate datasets, and remote sensing provides an opportunity to adapt existing and emerging econometric methods useful for identifying causal relationships from observational data (e.g., Athey and Imbens, 2017). Although there have been recent applications of causal inference to hydrological questions such as estimating streamflow reductions from deforestation (Levy et al., 2018), linking changes in impervious cover to changes in flood events (Blum et al., 2020), or assessing the impact of groundwater policy on pumping and water levels (Deines et al., 2019), these techniques have not yet been used for streamflow depletion assessments to our knowledge. Causal inference methods that would be well-suited to streamflow depletion include (i) difference-in-differences comparisons with appropriate analogs that can serve as a control, similar to paired-catchment studies (Kim et al., 2017; Reichert et al., 2017); (ii) Granger causality (Granger, 1969), which tests whether including a variable (e.g., pumping) improves predictions of the outcome (e.g., streamflow or baseflow); and (iii) statistical constructions of "counterfactual" scenarios. For the problem of streamflow depletion, these counterfactual methods (e.g., synthetic controls, Abadie et al., 2010 or causal impact, Brodersen et al., 2015) might use pre- and post-pumping relationships among streamflow in the area of interest and streamflow in nearby streams unaffected by pumping, along with covariates such as precipitation, to estimate what streamflow would have been in the absence of pumping as a counterfactual. Differences between observed 
streamflow and this counterfactual can then be attributed to streamflow depletion. Counterfactual methods have been used elsewhere to isolate impacts of climate and land use change on streamflow (Gao et al., 2016; Zhang et al., 2016; Zipper, Motew, et al., 2018). More information about causal inference methods is available in several recent reviews (Athey and Imbens, 2017; Ombadi et al., 2020; Runge et al., 2019). Ultimately, an effective use of causal inference requires thoughtful design and interpretation to match appropriate methods for the study system, account for confounding variables, and couch conclusions within the limitations of the method.

Machine learning, including deep learning, is another emerging statistical approach with potential applications for streamflow depletion estimation and causal inference because machine learning methods can control for many potential covariates (Athey and Imbens, 2017). Machine learning models more easily ingest and process large amounts of data compared to other statistical approaches and have the ability to detect unexpected patterns between data points (Nearing et al., 2020). Recent applications have shown the ability of machine learning models to provide better predictions than physically-based hydrological models of daily streamflow in both gaged and ungaged locations (Kratzert, Klotz, Herrnegger, et al., 2019; Kratzert, Klotz, Shalev, et al., 2019). While machine learning methods have been applied separately to estimate groundwater levels (Sahoo et al., 2017), groundwater use (Majumdar et al., 2020), streamflow change (Zipper, Hammond, et al., 2021), and surface water metrics (Worland et al., 2018), to the best our knowledge, they have not been applied to streamflow depletion (though machine learning techniques have been used for metamodeling of streamflow depletion trained on numerical model output, as described in the 'Numerical Models' section). Simple machine learning techniques such as random forests have the advantages of (i) allowing for many predictors with non-linear relationships to the response variable, (ii) not being constrained by our current best understanding of process across scales, (iii) reasonable transparency and interoperability through variable importance analysis, and (iv) strong performance in prediction mode with reproducible uncertainty estimates (Addor et al., 2018).

Despite these strengths, random forests and other machine learning techniques are limited

676 by their inability to extrapolate beyond the range of values in the input data (Beven, 2020),

677 which is problematic when the potential system stresses being analyzed, such as pumping

678 scenarios, exceed what has been experienced in existing monitored conditions. Additionally, a

679 lack of transparency in machine learning models can make them difficult to interpret, they

680 require large input training datasets, and predictions can be highly sensitive to small perturbations in input under certain circumstances (Shen, 2018). For a problem as complex as

682 estimating streamflow depletion, process-guided deep learning in which the model is penalized 683 for violating physical laws (e.g., Read et al., 2019) could prove useful. Machine learning may be 684 especially useful for estimating streamflow depletion due to their ability to identify connections 685 between seemingly unconnected variables, which is valuable given that the groundwater 686 pumping data are rarely monitored or available (Foster et al., 2019). 
687 Example Use in Management. Australia modified its water laws in 2004 to require conjunctive management of interconnected surface water and groundwater (Ross, 2018). To meet this need in Australia's Murray-Darling basin, which covers $>1$ million square kilometers, a joint approach combining numerical and statistical models was developed through the Murray-Darling Sustainable Yields Program and is described in Rassam et al. (2008). Because of the size and complexity of the Murray-Darling Basin, as well as the presence of existing surface water and groundwater models for parts of the basin, a single basin-wide integrated numerical model was not available or feasible to develop. Instead, to assess impacts of pumping on streamflow the program used existing or developed new numerical groundwater models for high priority subbasins (those with the greatest groundwater extraction and largest likely impacts on streamflow), and for lower priority basins used a statistical model. This mixed numerical-statistical approach was enabled by a substantial amount of long-term data available for the Murray-Darling Basin that was used to parameterize and evaluate both the numerical and statistical models. The statistical model estimates streamflow depletion as a function of the pumping rate, time since pumping began, and an empirical connectivity factor (Rassam et al., 2008). Effectively, the connectivity factor is equal to the proportion of pumping that is expected to be sourced from streamflow depletion over long time scales, where a lower value indicates less streamflow depletion caused by a given pumping volume (Walker et al., 2020a). This statistical model is then used to evaluate whether changes in pumping, for example caused by climate change, may impair rivers beyond sustainable diversion limits that are set at the basin and catchment levels (Walker et al., 2020b).

\section{CHOOSING A STREAMFLOW DEPLETION ESTIMATION APPROACH}

Earlier, we identified four general characteristics of a successful streamflow depletion estimation approach: it should be well-suited to local conditions, actionable, transparent, and reproducible. Here, we evaluate analytical, numerical, and statistical models as they relate to these characteristics and with respect to common streamflow depletion management questions (Table 1). Since any well-documented approach can be made both transparent and reproducible (with the exception of proprietary software or tools, as noted above), the primary factors to consider should be the degree to which an approach is well-suited to local conditions and is actionable. In practice, this requires that the approach adequately accounts for the diverse potential drivers of streamflow change (well-suited), and the approach can provide estimates of streamflow depletion and associated uncertainty with the data, expertise, and resources available (actionable).

Suitability and actionability can be balanced by following the parsimony axiom that the approach chosen should be as simple as possible, but no simpler (Figure 3). For streamflow depletion, a well-suited approach should be sufficiently detailed to account for all relevant processes affecting streamflow depletion to avoid errors caused by model inadequacy, while avoiding the inclusion of irrelevant processes to minimize poorly constrained parameters and feedbacks to avoid propagation error (Hill and Teideman, 2007; Saltelli, 2019). To be actionable, 
the producer of the depletion estimates should be familiar with the strengths and weaknesses of the approach, and have sufficient skill and resources to provide estimates of uncertainty caused by parameters narrow enough to guide decision-making and assimilate available data to minimize this uncertainty (Doherty and Simmons, 2013). Figure 3 illustrates the principal by showing how increased model complexity decreases inadequacy error (generally associated with improved model fit to data) and eventually increases propagation error (generally associated with inaccurate predictions and tested using data not included in model development).

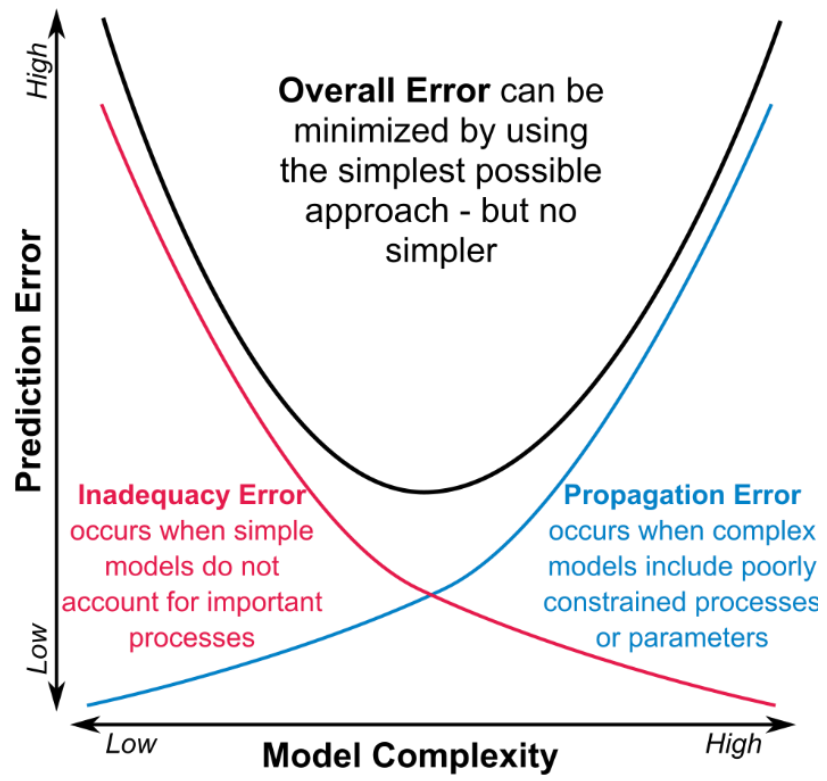

Figure 3. Considerations with respect to the relationship between model complexity and errors caused by inadequacy (red) and propagation (blue). Inspired by Saltelli (2019).

Balancing model simplicity and complexity is challenging and the subject of substantial discussion in the decision support modeling community. Past work has found that oversimplified models can underestimate uncertainty and bias model predictions, which hinders effective decision-making (Knowling et al., 2019), though stochastic statistical approaches can improve the simulated distribution of this bias (Farmer and Vogel, 2016). In practice, finding this balance is tricky and facilitated by experience with the technique being used, regional hydrologic expertise, and rigorous uncertainty analysis that identifies the processes and parameters contributing most to uncertainty (White et al., 2016; Leaf, 2017; Doherty and Moore, 2020).

Suitability primarily relates to the match between the management question being asked, the resources available, and the capabilities of each method (Table 3). For questions related to attribution ('Does pumping contribute to observed decreases in streamflow and, if so, how do pumping impacts compare to other drivers of change?'), numerical and statistical models are generally better-suited than analytical models. Both approaches can be designed to account for other potential drivers of streamflow change (such as land use or climate change). In contrast, analytical models are typically focused on groundwater pumping and do not include any other 
processes. Comparing between numerical and statistical models, numerical models can estimate causation more directly due to the direct representation of process-based links between different aspects of the interconnected stream-aquifer system, while statistical models typically provide

754 correlative results (though emerging statistical causal inference methods may be able to

755 overcome this limitation with further research; see, for example, Levy et al., 2018 and Blum et

756 al., 2020).

757 Table 3. Non-exhaustive list of major pros and cons of streamflow depletion estimation approaches for

758 management questions.

\begin{tabular}{|c|c|c|c|}
\hline Question & Analytical Models & Numerical Models & Statistical Models \\
\hline $\begin{array}{l}\text { Attribution: Does } \\
\text { pumping } \\
\text { contribute to } \\
\text { decreases in } \\
\text { streamflow and, } \\
\text { if so, how do } \\
\text { pumping impacts } \\
\text { compare to other } \\
\text { drivers of } \\
\text { change? }\end{array}$ & $\begin{array}{l}\text { PRO: can estimate potential } \\
\text { contribution of pumping to } \\
\text { streamflow change, and see } \\
\text { whether it is comparable in } \\
\text { magnitude to observed } \\
\text { change } \\
\text { CON: cannot assess other } \\
\text { potential drivers of } \\
\text { streamflow change }\end{array}$ & $\begin{array}{l}\text { PRO: can do causal } \\
\text { assessment of different } \\
\text { potential drivers of } \\
\text { streamflow change } \\
\text { CON: large user input data } \\
\text { requirements and challenging } \\
\text { to calibrate/validate }\end{array}$ & $\begin{array}{l}\text { PRO: able to account for } \\
\text { many potential drivers of } \\
\text { change (land use change, etc.) } \\
\text { as covariates in addition to } \\
\text { pumping } \\
\text { CON: typically provide } \\
\text { correlative, rather than } \\
\text { causative, results, which limit } \\
\text { ability to make attributive } \\
\text { claims }\end{array}$ \\
\hline $\begin{array}{l}\text { Impacts: What } \\
\text { are the } \\
\text { implications of } \\
\text { streamflow } \\
\text { depletion for } \\
\text { water users, } \\
\text { ecosystems, and } \\
\text { society? }\end{array}$ & $\begin{array}{l}\text { PRO: simple, straightforward } \\
\text { depletion estimate with } \\
\text { minimal data input allows for } \\
\text { rapid impact assessment } \\
\text { CON: does not account for } \\
\text { complex feedbacks e.g. } \\
\text { associated with changes in } \\
\text { recharge due to return flows }\end{array}$ & $\begin{array}{l}\text { PRO: can explore spatially } \\
\text { distributed impacts of } \\
\text { pumping on streamflow and } \\
\text { other parts of the socio- } \\
\text { environmental system } \\
\text { (groundwater depletion, } \\
\text { phreatophytic } \\
\text { evapotranspiration) } \\
\text { CON: complex model } \\
\text { structures challenging to } \\
\text { integrate with other system } \\
\text { and/or socio-economic } \\
\text { models }\end{array}$ & $\begin{array}{l}\text { PRO: flexible to different } \\
\text { input datasets and target } \\
\text { metrics, including target } \\
\text { metrics that cannot be } \\
\text { simulated by other } \\
\text { approaches } \\
\text { CON: only provide } \\
\text { information about target } \\
\text { metrics; often do not provide } \\
\text { spatiotemporal granularity of } \\
\text { other approaches }\end{array}$ \\
\hline $\begin{array}{l}\text { Mitigation: How } \\
\text { can streamflow } \\
\text { depletion be } \\
\text { mitigated? }\end{array}$ & $\begin{array}{l}\text { PRO: provide transient } \\
\text { estimates of changes in } \\
\text { streamflow expected for } \\
\text { different pumping scenarios } \\
\text { CON: cannot provide } \\
\begin{array}{l}\text { information about anything } \\
\text { except pumping (unable to } \\
\text { assess land use change }\end{array}\end{array}$ & $\begin{array}{l}\text { PRO: allow for exploration of } \\
\text { diverse scenarios related to } \\
\text { land use, climate change, } \\
\text { augmentation, etc., including } \\
\text { rigorous uncertainty and risk } \\
\text { assessment } \\
\text { CON: can appear realistic } \\
\text { even when processes are }\end{array}$ & $\begin{array}{l}\text { PRO: low computational } \\
\text { costs allow for rapid } \\
\text { exploration of many different } \\
\text { scenarios and uncertainty } \\
\text { CON: challenging to conduct } \\
\text { 'what-if' scenario analysis for } \\
\text { processes not included in } \\
\text { model structure, and lack of }\end{array}$ \\
\hline
\end{tabular}


759

760

761

762

763

764

765

766

767

768

769

770

771

772

773

774

775

776

777

778

779

780

781

782

783

784

785

786

787

788

789

790

791

792

793

\begin{tabular}{|l|l|l|l|}
\hline impacts, etc) & $\begin{array}{l}\text { poorly constrained; high } \\
\text { computational cost can limit } \\
\text { ability to test scenarios }\end{array}$ & $\begin{array}{l}\text { causality in some approaches } \\
\text { can limit mitigation } \\
\text { evaluation }\end{array}$ \\
\hline
\end{tabular}

The three approaches have similar suitability strengths and weaknesses for questions related to impacts ('What are the implications of streamflow depletion for water users, ecosystems, and society?') and mitigation ('How can streamflow depletion be mitigated?'). Analytical models are best-suited for assessing the impacts of a single well, while numerical and statistical models are better-suited for answering questions about regional-scale impacts of numerous pumping wells. Regardless of the approach used, it is critical that the estimation model is designed to match the management question and decision criteria. For example, regional numerical models are not well-designed for assessing streamflow depletion from a single well because their grid size typically does not allow sufficient spatial refinement to accurately capture fine-scale dynamics, and they can only detect impacts that exceed the mass balance error of the model (Konikow and Bredehoeft, 1992; Mehl and Hill, 2010). For a single well, localized numerical models with fine grids and tight solver criteria can be developed (Feinstein et al., 2016). Numerical models tend to be best-suited to explore spatially- and temporally-distributed impacts of pumping on multiple aspects of the hydrological and broader socio-environmental system because they can include explicit process-based coupling among different processes (i.e., streamflow depletion, phreatophytic evapotranspiration, groundwater depletion) and are increasingly coupled to other models such as agent-based or economic models (Castilla-Rho et al., 2015, 2017; Hu et al., 2017; Rouhi Rad et al., 2020).

Where there is a specific management target, statistical models may be advantageous since they can be developed for that metric and therefore bypass complexity associated with other aspects of the system. For example, if management decisions require understanding how pumping will change $10^{\text {th }}$ percentile annual streamflow, there is no need to simulate impacts on daily or monthly streamflow, significantly reducing statistical model complexity and allowing rigorous uncertainty and sensitivity analysis associated with this hydrologic signature. This is in contrast to numerical models which need to proceed through a more complete representation of the entire hydrological cycle, which means that statistical models can be significantly less complex but may also be more narrowly focused. Additionally, if estimates are needed for different climate conditions (past or future), it is critical that the approach selected acknowledges and, ideally, accounts for hydrologic non-stationarity associated with climate change (Milly et al., 2008; Rissman and Wardropper, 2020).

Actionability, on the other hand, is driven by the availability of data, resources, and expertise. In general, as model complexity increases, so too do the data and resources required for their applications. In general, analytical models have the lowest complexity, statistical models have intermediate complexity, and numerical models can be the most complex, though 
794 there is substantial variability within each of these three broad categories (Figure 4).

795 Interestingly, Addor and Melsen (2019) showed that the choice of hydrological models is

796 strongly influenced by the training and institution of the modeler (Addor and Melsen, 2019), and

797 it is therefore likely that expertise and preferred methods will vary across water management

798 areas based on their region, staff, and history. However, analytical models tend to require less

799 expertise to develop and implement than numerical models, which may make them feasible in 800 resource-limited locations (Zipper, Dallemagne, et al., 2018). Analytical, numerical, and

801 statistical models would all benefit from improved data collection for key streamflow depletion 802 processes, in particular the location, volume, and timing of groundwater withdrawals which is 803 often only available in very well-monitored or studied regions (Foster et al., 2019).

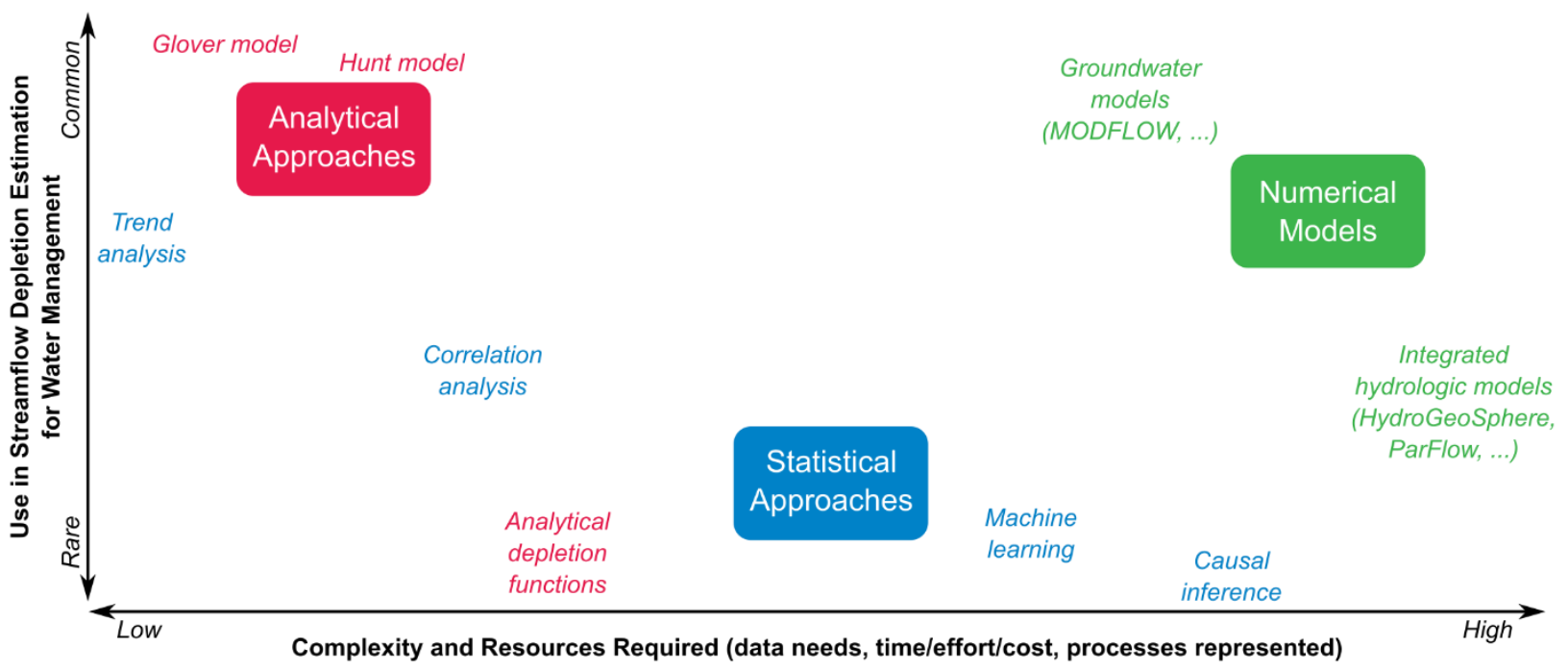

Figure 4. Comparison of analytical, statistical, and numerical approaches with respect to complexity and use for streamflow depletion estimation. Large colored boxes show the general type of approach, and smaller colored text shows specific methods/tools. Locations of approaches in the graph are based on author discussions and informal feedback from colleagues. represented. When the focus of study is the impacts of a single well on a single stream, then analytical models are likely to be the best tool for the job. For questions regional in scale, statistical or numerical models are likely to be more suitable. Statistical models, which provide an intermediate level of complexity between numerical and analytical approaches, have not been widely used for streamflow depletion estimation due to the lack of causal attribution but may be a promising area for future development. Given the contrasting strengths and weaknesses of the three approaches discussed above, there is likely to be significant value in using multiple approaches to help constrain estimates (Saltelli et al., 2020). 
Reliable estimates of streamflow depletion are essential for effective water management in settings with interconnected groundwater and surface water resources. We categorize common water management questions into three groups based on water management goals: (1) attribution, to understand the potential drivers of changes in observed streamflow; (2) impacts, to understand the hydrological, ecological, or socio-economic ramifications of streamflow depletion; and (3) mitigation, to identify ways that the impacts of streamflow depletion can be reduced or minimized. Making management decisions related to each of these goals requires accurate estimates of streamflow depletion, but quantifying streamflow depletion is challenging because it cannot be directly observed in typical hydrological data (i.e., streamflow hydrographs) and therefore is infeasible to estimate using field techniques at scales larger than a single stream reach. Due to these difficulties, there has historically been a lack of consistent streamflow depletion regulatory frameworks, which has caused local water managers to make decisions on a case-by-case basis.

In this study, we provide an updated review of analytical, numerical, and statistical approaches for regional-scale streamflow depletion estimates. From this effort, we developed criteria that water managers can use to select an appropriate and feasible approach for their needs based on suitability, actionability, transparency, and reproducibility. The approach selected should be well-suited to local conditions, produce actionable information relevant to the water management question under consideration, be transparent to stakeholders such as water users affected by the decision, and be reproducible so it can be evaluated and used by others not involved in the quantification process.

We then used these criteria to evaluate analytical, numerical, and statistical models, finding that the strengths and weaknesses of each approach vary based on the management question being addressed. Analytical models are well-suited for rapid, screening-level assessments of potential impacts and implications of streamflow depletion, but they struggle with questions related to attribution and mitigation since they rarely include other processes that could affect streamflow. Numerical models are particularly well-suited for understanding impacts of pumping and mitigation for streamflow depletion because they can include quantitative links among many different processes and are increasingly coupled to models representing other aspects of the local social and hydrological system. Numerical models are currently the gold standard for streamflow depletion estimation, but can be infeasible in many settings with limited resources. Statistical approaches have not seen wide use for streamflow depletion estimation compared to analytical or numerical approaches because they typically provide correlative, rather than causative, output and therefore struggle with questions related to attribution and impacts. However, emerging statistical methods for causal attribution may become a new tool in the water management toolbox, and with further development could provide a valuable intermediatecomplexity approach for streamflow depletion estimation to fill the gap between simple analytical models and complex numerical models. Additionally, blended approaches (i.e., 
developing statistical metamodels to interpret and extend numerical model output) can leverage the strengths of multiple types of approaches and hold promise for future use.

Regardless of the approach selected, it is critical to calculate and communicate the uncertainty associated with streamflow depletion estimates, particularly when extrapolating any approach beyond the conditions in which it was developed (i.e., scenario assessment). By being transparent about strengths, weaknesses, and uncertainties, stakeholders will better understand the logic behind decisions and can serve as a bridge to participatory approaches to streamflow depletion estimation that can enhance both scientific quality and societal impact.

\section{APPENDIX 1: STAKEHOLDER FEEDBACK}

To help guide this manuscript towards relevant, actionable information for water managers, we had conversations with five different stakeholders asking for their feedback on an earlier draft of the manuscript. In these conversations, we shared a draft version of the manuscript and an executive summary of the key points, with the following conversation prompts in advance:

1. What types of decisions or recommendations do you make related to streamflow depletion?

2. What do you use - data, software, equations, or other tools - to make those decisions?

3. What barriers have you encountered to using streamflow depletion information for decisionmaking?

4. Please look at the figure on page 1 [note: this is the current Figure 2]. What about this figure aligns with your own decision process? What is different? What are we missing?

5. What information would make this paper most useful to people like you?

6. Any other thoughts or comments?

These questions provided a basis for the conversation, but we allowed the stakeholders to focus on aspects that were most interesting and relevant to them, so not all questions were directly addressed by all stakeholders.

\section{ACKNOWLEDGMENTS}

This work was conducted as a part of the Streamflow Depletion Across the U.S. Working Group supported by the John Wesley Powell Center for Analysis and Synthesis, funded by the U.S. Geological Survey. Thanks to Chris Beightel, Melissa Rohde, Bob Smail, and the rest of the Powell Center working group for feedback. We also appreciate constructive feedback from Paul Barlow, Ryan Bailey, and three anonymous reviewers. Any use of trade, firm, or product names is for descriptive purposes only and does not imply endorsement by the U.S. Government.

\section{LITERATURE CITED}

Abadie, A., A. Diamond, and J. Hainmueller, 2010. Synthetic Control Methods for Comparative Case Studies: Estimating the Effect of California's Tobacco Control Program. Journal of the American Statistical Association 105:493-505. 
Abbott, B.W., K. Bishop, J.P. Zarnetske, C. Minaudo, F.S. Chapin, S. Krause, D.M. Hannah, L. Conner, D. Ellison, S.E. Godsey, S. Plont, J. Marçais, T. Kolbe, A. Huebner, R.J. Frei, T. Hampton, S. Gu, M. Buhman, S. Sara Sayedi, O. Ursache, M. Chapin, K.D. Henderson, and G. Pinay, 2019. Human Domination of the Global Water Cycle Absent from Depictions and Perceptions. Nature Geoscience 12:533-540.

Abimbola, O.P., A.R. Mittelstet, T.E. Gilmore, and J.T. Korus, 2020. Influence of Watershed Characteristics on Streambed Hydraulic Conductivity across Multiple Stream Orders. Scientific Reports 10:3696.

Addor, N. and L.A. Melsen, 2019. Legacy, Rather Than Adequacy, Drives the Selection of Hydrological Models. Water Resources Research 55:378-390.

Addor, N., G. Nearing, C. Prieto, A.J. Newman, N.L. Vine, and M.P. Clark, 2018. A Ranking of Hydrological Signatures Based on Their Predictability in Space. Water Resources Research 54:8792-8812.

Ahlfeld, D.P., J.C. Schneider, and C.P. Spalding, 2016. Effects of Nonlinear Model Response on Allocation of Streamflow Depletion: Exemplified by the Case of Beaver Creek, USA. Hydrogeology Journal 24:1835-1845.

Arthington, A.H., A. Bhaduri, S.E. Bunn, S.E. Jackson, R.E. Tharme, D. Tickner, B. Young, M. Acreman, N. Baker, S. Capon, A.C. Horne, E. Kendy, M.E. McClain, N.L. Poff, B.D. Richter, and S. Ward, 2018. The Brisbane Declaration and Global Action Agenda on Environmental Flows (2018). Frontiers in Environmental Science 6. doi:10.3389/fenvs.2018.00045.

Asher, M.J., B.F.W. Croke, A.J. Jakeman, and L.J.M. Peeters, 2015. A Review of Surrogate Models and Their Application to Groundwater Modeling. Water Resources Research 51:5957-5973.

Athey, S. and G.W. Imbens, 2017. The State of Applied Econometrics: Causality and Policy Evaluation. Journal of Economic Perspectives 31:3-32.

Ayers, J.R., G. Villarini, C. Jones, and K. Schilling, 2019. Changes in Monthly Baseflow across the U.S. Midwest. Hydrological Processes 33:748-758.

Bakker, M., V. Post, C.D. Langevin, J.D. Hughes, J.T. White, J.J. Starn, and M.N. Fienen, 2016. Scripting MODFLOW Model Development Using Python and FloPy. Groundwater 54:733-739.

Barlow, P.M. and S.A. Leake, 2012. Streamflow Depletion by Wells--Understanding and Managing the Effects of Groundwater Pumping on Streamflow. U.S. Geological Survey, Reston VA. https://pubs.usgs.gov/circ/1376/. 
Barlow, P.M., S.A. Leake, and M.N. Fienen, 2018. Capture Versus Capture Zones: Clarifying Terminology Related to Sources of Water to Wells. Groundwater 56:694-704.

Beven, K., 2006. A Manifesto for the Equifinality Thesis. Journal of Hydrology 320:18-36.

Beven, K., 2020. Deep Learning, Hydrological Processes and the Uniqueness of Place. Hydrological Processes 34:3608-3613.

Biggs, T., A. Gaur, C. Scott, P. Thenkabail, P. Gangadhara Rao, M.K. Gumma, S. Acharya, and H. Turral, 2007. Closing of the Krishna Basin: Irrigation, Streamflow Depletion and Macroscale Hydrology. IWMI.

Blum, A.G., P.J. Ferraro, S.A. Archfield, and K.R. Ryberg, 2020. Causal Effect of Impervious Cover on Annual Flood Magnitude for the United States. Geophysical Research Letters 47:e2019GL086480.

Boyce, S.E., R.T. Hanson, I. Ferguson, W. Schmid, W.R. Henson, T. Reimann, S.W. Mehl, and M.M. Earll, 2020. One-Water Hydrologic Flow Model: A MODFLOW Based Conjunctive-Use Simulation Software. USGS Numbered Series, U.S. Geological Survey, Reston, VA.

Bredehoeft, J.D. and R.A. Young, 1983. Conjunctive Use of Groundwater and Surface Water for Irrigated Agriculture: Risk Aversion. Water Resources Research 19:1111-1121.

Bredehoeft, J.D., 2011. Monitoring Regional Groundwater Extraction: The Problem. Groundwater 49:808-814.

Brodersen, K.H., F. Gallusser, J. Koehler, N. Remy, and S.L. Scott, 2015. Inferring Causal Impact Using Bayesian Structural Time-Series Models. Annals of Applied Statistics 9:247-274.

Brookfield, A.E. and C. Gnau, 2016. Optimizing Water Management for Irrigation Under Climate Uncertainty: Evaluating Operational and Structural Alternatives in the Lower Republican River Basin, Kansas, USA. Water Resources Management 30:607-622.

Brookfield, A., C. Gnau, and B. Wilson, 2017. Incorporating Surface Water Operations in an Integrated Hydrologic Model: Model Development and Application to the Lower Republican River Basin, United States. Journal of Hydrologic Engineering 22:04016065.

Burt, O.R., M. Baker, and G.A. Helmers, 2002. Statistical Estimation of Streamflow Depletion from Irrigation Wells. Water Resources Research 38:32-1-32-13.

Butler, J.J., X. Zhan, and V.A. Zlotnik, 2007. Pumping-Induced Drawdown and Stream Depletion in a Leaky Aquifer System. Ground Water 45:178-186. 
Camporese, M., C. Paniconi, M. Putti, and S. Orlandini, 2010. Surface-Subsurface Flow Modeling with Path-Based Runoff Routing, Boundary Condition-Based Coupling, and Assimilation of Multisource Observation Data. Water Resources Research 46:W02512.

Castilla-Rho, J.C., G. Mariethoz, R. Rojas, M.S. Andersen, and B.F.J. Kelly, 2015. An AgentBased Platform for Simulating Complex Human-Aquifer Interactions in Managed Groundwater Systems. Environmental Modelling \& Software 73:305-323.

Castilla-Rho, J.C., R. Rojas, M.S. Andersen, C. Holley, and G. Mariethoz, 2017. Social Tipping Points in Global Groundwater Management. Nature Human Behaviour 1:640.

Christensen, S., 2000. On the Estimation of Stream Flow Depletion Parameters by Drawdown Analysis. Groundwater 38:726-734.

Condon, L.E. and R.M. Maxwell, 2013. Implementation of a Linear Optimization Water Allocation Algorithm into a Fully Integrated Physical Hydrology Model. Advances in Water Resources 60:135-147.

Condon, L.E. and R.M. Maxwell, 2014. Feedbacks between Managed Irrigation and Water Availability: Diagnosing Temporal and Spatial Patterns Using an Integrated Hydrologic Model. Water Resources Research 50:2600-2616.

Condon, L.E. and R.M. Maxwell, 2019. Simulating the Sensitivity of Evapotranspiration and Streamflow to Large-Scale Groundwater Depletion. Science Advances 5:eaav4574.

Deines, J.M., A.D. Kendall, J.J. Butler, and D.W. Hyndman, 2019. Quantifying Irrigation Adaptation Strategies in Response to Stakeholder-Driven Groundwater Management in the US High Plains Aquifer. Environmental Research Letters 14:044014.

Dickert, N. and J. Sugarman, 2005. Ethical Goals of Community Consultation in Research. American Journal of Public Health 95:1123-1127.

Doherty, J. and C. Moore, 2020. Decision Support Modeling: Data Assimilation, Uncertainty Quantification, and Strategic Abstraction. Groundwater 58:327-337.

Doherty, J. and C.T. Simmons, 2013. Groundwater Modelling in Decision Support: Reflections on a Unified Conceptual Framework. Hydrogeology Journal 21:1531-1537.

Eker, S., E. Rovenskaya, M. Obersteiner, and S. Langan, 2018. Practice and Perspectives in the Validation of Resource Management Models. Nature Communications 9:5359.

Enemark, T., L.J.M. Peeters, D. Mallants, and O. Batelaan, 2019. Hydrogeological Conceptual Model Building and Testing: A Review. Journal of Hydrology 569:310-329.

Environment Canterbury, 2020. Groundwater Tools and Resources. Environment Canterbury. 
https://www.ecan.govt.nz/your-region/your-environment/water/tools-and-resources/. Accessed 8 May 2020.

Evans, R., M. Dudding, and G. Holland, 2006. River-Groundwater Interaction: A Practical Management Approach. Australasian Journal of Water Resources 10:171-178.

Fang, K., D. Kifer, K. Lawson, and C. Shen, 2020. Evaluating the Potential and Challenges of an Uncertainty Quantification Method for Long Short-Term Memory Models for Soil Moisture Predictions. Water Resources Research 56:e2020WR028095.

Farmer, W.H. and R.M. Vogel, 2016. On the Deterministic and Stochastic Use of Hydrologic Models. Water Resources Research 52:5619-5633.

Farmer, W.H., S.A. Archfield, T.M. Over, L.E. Hay, J.H. LaFontaine, and J.E. Kiang, 2014. A Comparison of Methods to Predict Historical Daily Streamflow Time Series in the Southeastern United States. US Geological Survey.

Ferré, T.P., 2017. Revisiting the Relationship between Data, Models, and Decision-Making. Groundwater 55:604-614.

Feinstein, D.T., M.N. Fienen, H.W. Reeves, and C.D. Langevin, 2016. A Semi-Structured MODFLOW-USG Model to Evaluate Local Water Sources to Wells for Decision Support. Groundwater 54:532-544.

Fienen, M.N., K.R. Bradbury, M. Kniffin, and P.M. Barlow, 2018. Depletion Mapping and Constrained Optimization to Support Managing Groundwater Extraction. Groundwater $56: 18-31$.

Fienen, M.N., B.T. Nolan, and D.T. Feinstein, 2016. Evaluating the Sources of Water to Wells: Three Techniques for Metamodeling of a Groundwater Flow Model. Environmental Modelling \& Software 77:95-107.

Fienen, M.N., B.T. Nolan, D.T. Feinstein, and J.J. Starn, 2015. Metamodels to Bridge the Gap Between Modeling and Decision Support. Groundwater 53:511-512.

Fienen, M.N., B.T. Nolan, L.J. Kauffman, and D.T. Feinstein, 2018. Metamodeling for Groundwater Age Forecasting in the Lake Michigan Basin. Water Resources Research $54: 4750-4766$.

Fienen, M.N., N.T. Corson-Dosch, J.T. White, A.T. Leaf, and R.J. Hunt, 2021. Risk-Based Wellhead Protection Decision Support: A Repeatable Workflow Approach. Groundwater. doi:10.1111/gwat.13129.

Foster, L.K., J.T. White, A.T. Leaf, N.A. Houston, and A. Teague, 2021. Risk-Based DecisionSupport Groundwater Modeling for the Lower San Antonio River Basin, Texas, USA. 
Groundwater 59:581-596.

1027 Foster, T., I.Z. Gonçalves, I. Campos, C.M.U. Neale, and N. Brozović, 2019. Assessing

1028

1029

1030

1031

1032

1033

1034

1035

1036

1037

1038

1039

1040

1041

1042

1043

1044

1045

1046

1047

1048

1049

1050

1051

1052

1053

1054

1055

1056

1057

1058

1059 Landscape Scale Heterogeneity in Irrigation Water Use with Remote Sensing and in Situ Monitoring. Environmental Research Letters 14:024004.

Foster, T., T. Mieno, and N. Brozović, 2020. Satellite-Based Monitoring of Irrigation Water Use: Assessing Measurement Errors and Their Implications for Agricultural Water Management Policy. Water Resources Research 56:e2020WR028378.

Gage, A. and A. Milman, 2020. Groundwater Plans in the United States: Regulatory Frameworks and Management Goals. Groundwater. doi:10.1111/gwat.13050.

Gao, Z., L. Zhang, X. Zhang, L. Cheng, N. Potter, T. Cowan, and W. Cai, 2016. Long-Term Streamflow Trends in the Middle Reaches of the Yellow River Basin: Detecting Drivers of Change. Hydrological Processes 30:1315-1329.

Gardner, M.A., C.G. Morton, J.L. Huntington, R.G. Niswonger, and W.R. Henson, 2018. Input Data Processing Tools for the Integrated Hydrologic Model GSFLOW. Environmental Modelling \& Software 109:41-53.

Gleeson, T., W.M. Alley, D.M. Allen, M.A. Sophocleous, Y. Zhou, M. Taniguchi, and J. VanderSteen, 2012. Towards Sustainable Groundwater Use: Setting Long-Term Goals, Backcasting, and Managing Adaptively. Ground Water 50:19-26.

Gleeson, T., M. Cuthbert, G. Ferguson, and D. Perrone, 2020. Global Groundwater Sustainability, Resources, and Systems in the Anthropocene. Annual Review of Earth and Planetary Sciences 48:null.

Gleeson, T. and B. Richter, 2018. How Much Groundwater Can We Pump and Protect Environmental Flows through Time? Presumptive Standards for Conjunctive Management of Aquifers and Rivers. River Research and Applications 34:83-92.

Gleeson, T., L. Wang-Erlandsson, M. Porkka, S.C. Zipper, F. Jaramillo, D. Gerten, I. Fetzer, S.E. Cornell, L. Piemontese, L.J. Gordon, J. Rockström, T. Oki, M. Sivapalan, Y. Wada, K.A. Brauman, M. Flörke, M.F.P. Bierkens, B. Lehner, P. Keys, M. Kummu, T. Wagener, S. Dadson, T.J. Troy, W. Steffen, M. Falkenmark, and J.S. Famiglietti, 2020. Illuminating Water Cycle Modifications and Earth System Resilience in the Anthropocene. Water Resources Research 56:e2019WR024957.

Glover, R.E. and G.G. Balmer, 1954. River Depletion Resulting from Pumping a Well near a River. Eos, Transactions American Geophysical Union 35:468-470.

de Graaf, I.E.M., T. Gleeson, L.P.H. (Rens) van Beek, E.H. Sutanudjaja, and M.F.P. Bierkens, 2019. Environmental Flow Limits to Global Groundwater Pumping. Nature 574:90-94. 
1060

1061

1062

1063

1064

1065

1066

1067

1068

1069

1070

1071

1072

1073

1074

1075

1076

1077

1078

1079

1080

1081

1082

1083

1084

1085

1086

1087

1088

1089

1090

1091

Granger, C.W., 1969. Investigating Causal Relations by Econometric Models and Cross-Spectral Methods. Econometrica: Journal of the Econometric Society:424-438.

Hantush, M.S., 1965. Wells near Streams with Semipervious Beds. Journal of Geophysical Research 70:2829-2838.

Harsha, J., 2016. Conjunctive Use of Surface and Ground Water in India: Need to Revisit the Strategy. Geological Society of India 2016 Conference on Integrated and Sustainable Water Management: Science and Technology, pp. 145-153.

Hill, M.C., 2006. The Practical Use of Simplicity in Developing Ground Water Models. Groundwater 44:775-781.

Hill, M.C. and C.R. Tiedeman, 2006. Effective Groundwater Model Calibration: With Analysis of Data, Sensitivities, Predictions, and Uncertainty. John Wiley \& Sons.

Hill, M.C., G.P. Lennon, G.A. Brown, C.S. Hebson, and S.J. Rheaume, 1992. Geohydrology of, and Simulation of Ground-Water Flow in, the Valley-Fill Deposits in the Ramapo River Valley, New Jersey. U.S. Geological Survey, West Trenton, NJ.

Holtschlag, D.J., 2019. Basin, Climatic, and Irrigation Factors Associated with Median Summer Water Yields for Streams in Southwestern Michigan, 1945-2015. U.S. Geological Survey. doi:10.3133/sir20185071.

Hu, Y., C.J. Quinn, X. Cai, and N.W. Garfinkle, 2017. Combining Human and Machine Intelligence to Derive Agents' Behavioral Rules for Groundwater Irrigation. Advances in Water Resources 109:29-40.

Huang, C.-S., T. Yang, and H.-D. Yeh, 2018. Review of Analytical Models to Stream Depletion Induced by Pumping: Guide to Model Selection. Journal of Hydrology 561:277-285.

Huggins, X., T. Gleeson, H. Eckstrand, and B. Kerr, 2018. Streamflow Depletion Modeling: Methods for an Adaptable and Conjunctive Water Management Decision Support Tool. JAWRA Journal of the American Water Resources Association 54:1024-1038.

Hunt, B., 1999. Unsteady Stream Depletion from Ground Water Pumping. Ground Water 37:98102.

Hunt, B., 2003. Unsteady Stream Depletion When Pumping from Semiconfined Aquifer. Journal of Hydrologic Engineering 8:12-19.

Hunt, B., 2014. Review of Stream Depletion Solutions, Behavior, and Calculations. Journal of Hydrologic Engineering 19:167-178.

Hunt, R.J., M.N. Fienen, and J.T. White, 2020. Revisiting “An Exercise in Groundwater Model 
Calibration and Prediction" After 30 Years: Insights and New Directions. Groundwater $58: 168-182$.

Hunt, B., J. Weir, and B. Clausen, 2001. A Stream Depletion Field Experiment. Ground Water 39:283-289.

Hwang, H.-T., Y.-J. Park, S.K. Frey, M.V. Callaghan, S.J. Berg, D.R. Lapen, and E.A. Sudicky, 2019. Efficient Numerical Incorporation of Water Management Operations in Integrated Hydrosystem Models: Application to Tile Drainage and Reservoir Operating Systems. Journal of Hydrology 575:1253-1266.

Idaho Water Resource Board, 2019. Restoring the Eastern Snake Plain Aquifer. https://idwr.idaho.gov/files/iwrb/2019/20191210-ESPA-CAMP-Progess-ReportFinal.pdf.

Jenkins, C.T., 1968. Techniques for Computing Rate and Volume of Stream Depletion by Wells. Ground Water 6:37-46.

Jenkins, C.T. and O.J. Taylor, 1972. Stream Depletion Factors, Arkansas River Valley, Southeastern Colorado; A Basis for Evaluating Plans for Conjunctive Use of Ground and Surface Water. U.S. Geological Survey.

Juracek, K.E., 2015. Streamflow Characteristics and Trends at Selected Streamgages in Southwest and South-Central Kansas. USGS Numbered Series, U.S. Geological Survey, Reston, VA.

Kallis, G. and D. Butler, 2001. The EU Water Framework Directive: Measures and Implications. Water Policy 3:125-142.

Karpatne, A., I. Ebert-Uphoff, S. Ravela, H.A. Babaie, and V. Kumar, 2019. Machine Learning for the Geosciences: Challenges and Opportunities. IEEE Transactions on Knowledge and Data Engineering 31:1544-1554.

KDA-DWR, 2019. Formal Response to Feb 22, 2019 LEMA Proposal. Kansas Department of Agriculture-Division of Water Resources. https://agriculture.ks.gov/docs/defaultsource/dwr-water-appropriation-documents/2019-0730formalresponsetofeb20191ema_request.pdf?sfvrsn=e5d688c1_0.

Kelly, B.P. and P.H. Rydlund, Jr., 2006. Water-Quality Changes Caused by Riverbank Filtration Between the Missouri River and Three Pumping Wells of the Independence, Missouri, Well Field 2003-05. US Geological Survey. https://pubs.usgs.gov/sir/2006/5174/.

Kendy, E. and J.D. Bredehoeft, 2006. Transient Effects of Groundwater Pumping and SurfaceWater-Irrigation Returns on Streamflow. Water Resources Research 42:W08415. 
Kim, J., T. Hwang, C.L. Schaaf, D.A. Orwig, E. Boose, and J.W. Munger, 2017. Increased Water Yield Due to the Hemlock Woolly Adelgid Infestation in New England. Geophysical Research Letters 44:2016GL072327.

Kniffin, M., K.R. Bradbury, M. Fienen, and K. Genskow, 2020. Groundwater Model Simulations of Stakeholder-Identified Scenarios in a High-Conflict Irrigated Area. Groundwater. doi:10.1111/gwat.12989.

Knowling, M.J., J.T. White, G.W. McDonald, J.-H. Kim, C.R. Moore, and B. Hemmings, 2020. Disentangling Environmental and Economic Contributions to Hydro-Economic Model Output Uncertainty: An Example in the Context of Land-Use Change Impact Assessment. Environmental Modelling \& Software 127:104653.

Knowling, M.J., J.T. White, and C.R. Moore, 2019. Role of Model Parameterization in RiskBased Decision Support: An Empirical Exploration. Advances in Water Resources 128:59-73.

Kollet, S., M. Sulis, R.M. Maxwell, C. Paniconi, M. Putti, G. Bertoldi, E.T. Coon, E. Cordano, S. Endrizzi, E. Kikinzon, E. Mouche, C. Mügler, Y.-J. Park, J.C. Refsgaard, S. Stisen, and E. Sudicky, 2017. The Integrated Hydrologic Model Intercomparison Project, IHMIP2: A Second Set of Benchmark Results to Diagnose Integrated Hydrology and Feedbacks. Water Resources Research 53:867-890.

Kollet, S.J. and V.A. Zlotnik, 2003. Stream Depletion Predictions Using Pumping Test Data from a Heterogeneous Stream-Aquifer System (a Case Study from the Great Plains, USA). Journal of Hydrology 281:96-114.

Konar, M., M. Garcia, M.R. Sanderson, D.J. Yu, and M. Sivapalan, 2019. Expanding the Scope and Foundation of Sociohydrology as the Science of Coupled Human-Water Systems. Water Resources Research 55:874-887.

Konikow, L.F. and J.D. Bredehoeft, 1992. Ground-Water Models Cannot Be Validated. Advances in Water Resources 15:75-83.

Konikow, L.F. and S.A. Leake, 2014. Depletion and Capture: Revisiting "The Source of Water Derived from Wells". Groundwater 52:100-111.

Korus, J.T., W.P. Fraundorfer, T.E. Gilmore, and K. Karnik, 2020. Transient Streambed Hydraulic Conductivity in Channel and Bar Environments, Loup River, Nebraska. Hydrological Processes 34:3061-3077.

Korus, J.T., T.E. Gilmore, M.M. Waszgis, and A.R. Mittelstet, 2018. Unit-Bar Migration and Bar-Trough Deposition: Impacts on Hydraulic Conductivity and Grain Size Heterogeneity in a Sandy Streambed. Hydrogeology Journal 26:553-564. 
Kraft, G.J., K. Clancy, D.J. Mechenich, and J. Haucke, 2012. Irrigation Effects in the Northern Lake States: Wisconsin Central Sands Revisited. Groundwater 50:308-318.

Kratzert, F., D. Klotz, M. Herrnegger, A.K. Sampson, S. Hochreiter, and G.S. Nearing, 2019. Toward Improved Predictions in Ungauged Basins: Exploiting the Power of Machine Learning. Water Resources Research 55:11344-11354.

Kratzert, F., D. Klotz, G. Shalev, G. Klambauer, S. Hochreiter, and G. Nearing, 2019. Towards Learning Universal, Regional, and Local Hydrological Behaviors via Machine Learning Applied to Large-Sample Datasets. Hydrology and Earth System Sciences 23:5089-5110.

Kustu, M.D., Y. Fan, and A. Robock, 2010. Large-Scale Water Cycle Perturbation Due to Irrigation Pumping in the US High Plains: A Synthesis of Observed Streamflow Changes. Journal of Hydrology 390:222-244.

Larsen, L.G. and C. Woelfle-Erskine, 2018. Groundwater Is Key to Salmonid Persistence and Recruitment in Intermittent Mediterranean-Climate Streams. Water Resources Research 54:8909-8930.

Leaf, A.T., 2017. Using Models to Identify the Best Data: An Example from Northern Wisconsin. Groundwater 55:641-645.

Leaf, A.T., M.N. Fienen, R.J. Hunt, and C.A. Buchwald, 2015. Groundwater/Surface-Water Interactions in the Bad River Watershed, Wisconsin. USGS Numbered Series, U.S. Geological Survey, Reston, VA.

Leake, S.A., H.W. Reeves, and J.E. Dickinson, 2010. A New Capture Fraction Method to Map How Pumpage Affects Surface Water Flow. Groundwater 48:690-700.

Lee, H., M.-H. Koo, and Y. Kim, 2017. Impacts of Seasonal Pumping on Stream-Aquifer Interactions in Miryang, Korea. Groundwater 55:906-916.

Lee, H., M.-H. Koo, and S. Oh, 2019. Modeling Stream-Aquifer Interactions Under Seasonal Groundwater Pumping and Managed Aquifer Recharge. Groundwater 57:216-225.

Levy, M.C., A.V. Lopes, A. Cohn, L.G. Larsen, and S.E. Thompson, 2018. Land Use Change Increases Streamflow Across the Arc of Deforestation in Brazil. Geophysical Research Letters 45:3520-3530.

Li, Q., T. Gleeson, S.C. Zipper, and B. Kerr, 2021. Too Many Streams and Not Enough Time or Money? Analytical Depletion Functions for Streamflow Depletion Estimates. Groundwater. doi:10.1111/gwat.13124.

Li, Q., S.C. Zipper, and T. Gleeson, 2020. Streamflow Depletion from Groundwater Pumping in Contrasting Hydrogeological Landscapes: Evaluation and Sensitivity of a New 
Management Tool. Journal of Hydrology 590:125568.

1193

1194

1195

1196

1197

1198

1199

1200

1201

1202

1203

1204

1205

1206

1207

1208

1209

1210

1211

1212

1213

1214

1215

1216

1217

1218

1219

1220

1221

1222

1223

1224

1225

Liu, X., W. Liu, H. Yang, Q. Tang, M. Flörke, Y. Masaki, H. Müller Schmied, S. Ostberg, Y. Pokhrel, Y. Satoh, and Y. Wada, 2019. Multimodel Assessments of Human and Climate Impacts on Mean Annual Streamflow in China. Hydrology and Earth System Sciences 23:1245-1261.

Lowndes, J.S.S., B.D. Best, C. Scarborough, J.C. Afflerbach, M.R. Frazier, C.C. O’Hara, N. Jiang, and B.S. Halpern, 2017. Our Path to Better Science in Less Time Using Open Data Science Tools. Nature Ecology \& Evolution 1:0160.

Lucas, M.C., N. Kublik, D.B.B. Rodrigues, A.A. Meira Neto, A. Almagro, D. de C.D. Melo, S.C. Zipper, and P.T.S. Oliveira, 2021. Significant Baseflow Reduction in the Sao Francisco River Basin. Water 13:2.

Majumdar, S., R. Smith, J.J. Butler, and V. Lakshmi, 2020. Groundwater Withdrawal Prediction Using Integrated Multitemporal Remote Sensing Data Sets and Machine Learning. Water Resources Research 56:e2020WR028059.

Malek, K., C. Stöckle, K. Chinnayakanahalli, R. Nelson, M. Liu, K. Rajagopalan, M. Barik, and J.C. Adam, 2017. VIC-CropSyst-v2: A Regional-Scale Modeling Platform to Simulate the Nexus of Climate, Hydrology, Cropping Systems, and Human Decisions. Geoscientific Model Development 10:3059-3084.

Markstrom, S.L., R.G. Niswonger, R.S. Regan, D.E. Prudic, and P.M. Barlow, 2008. GSFLOW-Coupled Ground-Water and Surface-Water Flow Model Based on the Integration of the Precipitation-Runoff Modeling System (PRMS) and the Modular Ground-Water Flow Model (MODFLOW-2005). US Geological Survey Techniques and Methods 6-D1. Reston VA. https://pubs.usgs.gov/tm/tm6d1/.

McMillan, H., 2020. Linking Hydrologic Signatures to Hydrologic Processes: A Review. Hydrological Processes 34:1393-1409.

Mehl, S. and M.C. Hill, 2010. Grid-Size Dependence of Cauchy Boundary Conditions Used to Simulate Stream-Aquifer Interactions. Advances in Water Resources 33:430-442.

Michigan Water Use Advisory Council, 2020. Michigan Water Use Advisory Council 2020 Report. Michigan Department of Environment, Great Lakes, and Energy, Lansing, MI.

Miller, C.D., D. Durnford, M.R. Halstead, J. Altenhofen, and V. Flory, 2007. Stream Depletion in Alluvial Valleys Using the SDF Semianalytical Model. Groundwater 45:506-514.

Milly, P.C.D., J. Betancourt, M. Falkenmark, R.M. Hirsch, Z.W. Kundzewicz, D.P. Lettenmaier, and R.J. Stouffer, 2008. Stationarity Is Dead: Whither Water Management? Science 319:573-574.

Zipper et al. | Streamflow Depletion Review | 39 of 47 
1226

Moore, C. and J. Doherty, 2006. The Cost of Uniqueness in Groundwater Model Calibration. Advances in Water Resources 29:605-623.

Morway, E.D., R.G. Niswonger, and E. Triana, 2016. Toward Improved Simulation of River Operations through Integration with a Hydrologic Model. Environmental Modelling \& Software 82:255-274.

Munafò, M.R., B.A. Nosek, D.V.M. Bishop, K.S. Button, C.D. Chambers, N. Percie du Sert, U. Simonsohn, E.-J. Wagenmakers, J.J. Ware, and J.P.A. Ioannidis, 2017. A Manifesto for Reproducible Science. Nature Human Behaviour 1:0021.

Naz, B.S., W. Kurtz, C. Montzka, W. Sharples, K. Goergen, J. Keune, H. Gao, A. Springer, H.-J. Hendricks Franssen, and S. Kollet, 2019. Improving Soil Moisture and Runoff Simulations at $3 \mathrm{~km}$ over Europe Using Land Surface Data Assimilation. Hydrology and Earth System Sciences 23:277-301.

Nearing, G.S., F. Kratzert, A.K. Sampson, C.S. Pelissier, D. Klotz, J.M. Frame, C. Prieto, and H.V. Gupta, 2020. What Role Does Hydrological Science Play in the Age of Machine Learning? Water Resources Research:e2020WR028091.

Neupauer, R.M. and S.A. Griebling, 2012. Adjoint Simulation of Stream Depletion Due to Aquifer Pumping. Ground Water 50:746-753.

Neupauer, R.M., G. Lackey, and J. Pitlick, 2021. Exaggerated Stream Depletion in Streams with Spatiotemporally Varying Streambed Conductance. Journal of Hydrologic Engineering 26:04020066.

Ng, G.-H.C., A.D. Wickert, L.D. Somers, L. Saberi, C. Cronkite-Ratcliff, R.G. Niswonger, and J.M. McKenzie, 2018. GSFLOW-GRASS v1.0.0: GIS-Enabled Hydrologic Modeling of Coupled Groundwater-Surface-Water Systems. Geoscientific Model Development 11:4755-4777.

Niswonger, R.G., 2020. An Agricultural Water Use Package for MODFLOW and GSFLOW. Environmental Modelling \& Software 125:104617.

Niswonger, R.G., E.D. Morway, E. Triana, and J.L. Huntington, 2017. Managed Aquifer Recharge through Off-Season Irrigation in Agricultural Regions. Water Resources Research 53:6970-6992.

O’Keeffe, J., S. Moulds, E. Bergin, N. Brozović, A. Mijic, and W. Buytaert, 2018. Including Farmer Irrigation Behavior in a Sociohydrological Modeling Framework With Application in North India. Water Resources Research 54:4849-4866.

Ombadi, M., P. Nguyen, S. Sorooshian, and K. Hsu, 2020. Evaluation of Methods for Causal Discovery in Hydrometeorological Systems. Water Resources Research 
56:e2020WR027251.

1261 1262 1263

1264

1265 1266

1267

1268

1269

1270

1271

1272

1273

1274

1275

1276

1277

1278

1279

1280

1281

1282

1283

1284

1285 1286

1287

1288

1289

1290

1291

1292

1293

Opdam, P., J.I. Nassauer, Z. Wang, C. Albert, G. Bentrup, J.-C. Castella, C. McAlpine, J. Liu, S. Sheppard, and S. Swaffield, 2013. Science for Action at the Local Landscape Scale. Landscape Ecology 28:1439-1445.

Owen, D., A. Cantor, N.G. Nylen, T. Harter, and M. Kiparsky, 2019. California Groundwater Management, Science-Policy Interfaces, and the Legacies of Artificial Legal Distinctions. Environmental Research Letters 14:045016.

Paredes-Arquiola, J., J. Andreu-Álvarez, M. Martín-Monerris, and A. Solera, 2010. Water Quantity and Quality Models Applied to the Jucar River Basin, Spain. Water Resources Management 24:2759-2779.

Pathiraja, S., H. Moradkhani, L. Marshall, A. Sharma, and G. Geenens, 2018. Data-Driven Model Uncertainty Estimation in Hydrologic Data Assimilation. Water Resources Research 54:1252-1280.

Pedro-Monzonís, M., A. Solera, J. Ferrer, J. Andreu, and T. Estrela, 2016. Water Accounting for Stressed River Basins Based on Water Resources Management Models. Science of The Total Environment 565:181-190.

Penny, G., V. Srinivasan, R. Apoorva, K. Jeremiah, J. Peschel, S. Young, and S. Thompson, 2020. A Process-Based Approach to Attribution of Historical Streamflow Decline in a Data-Scarce and Human-Dominated Watershed. Hydrological Processes 34:1981-1995.

Perkin, J.S., K.B. Gido, J.A. Falke, K.D. Fausch, H. Crockett, E.R. Johnson, and J. Sanderson, 2017. Groundwater Declines Are Linked to Changes in Great Plains Stream Fish Assemblages. Proceedings of the National Academy of Sciences 114:7373-7378.

Pianosi, F., K. Beven, J. Freer, J.W. Hall, J. Rougier, D.B. Stephenson, and T. Wagener, 2016. Sensitivity Analysis of Environmental Models: A Systematic Review with Practical Workflow. Environmental Modelling \& Software 79:214-232.

Piazzi, G., G. Thirel, C. Perrin, and O. Delaigue, 2021. Sequential Data Assimilation for Streamflow Forecasting: Assessing the Sensitivity to Uncertainties and Updated Variables of a Conceptual Hydrological Model at Basin Scale. Water Resources Research 57. doi:10.1029/2020WR028390.

Prudic, D.E., R.G. Niswonger, and R.W. Plume, 2006. Trends in Streamflow on the Humboldt River between Elko and Imlay, Nevada, 1950-99. U.S. Geological Survey, Reston VA.

Rassam, D., G. Walker, and B. Barnett, 2008. Recommendations for Modelling SurfaceGroundwater Interactions Based on Lessons Learnt from the Murray-Darling Basin Sustainable Yields Project. CSIRO: Water for a Healthy Country Flagship. 
https://doi.org/10.4225/08/585ac69315dba. Accessed 18 Nov 2020.

1295

1296

1297

1298

1299

1300

1301

1302

1303

1304

1305

1306

1307

1308

1309

1310

1311

1312

1313

1314

1315

1316

1317

1318

1319

1320

1321

1322

1323

1324

1325

1326
Razavi, S., B.A. Tolson, and D.H. Burn, 2012. Review of Surrogate Modeling in Water Resources. Water Resources Research 48. doi:10.1029/2011WR011527.

Read, J.S., X. Jia, J. Willard, A.P. Appling, J.A. Zwart, S.K. Oliver, A. Karpatne, G.J.A. Hansen, P.C. Hanson, W. Watkins, M. Steinbach, and V. Kumar, 2019. Process-Guided Deep Learning Predictions of Lake Water Temperature. Water Resources Research 55:91739190.

Reed, M.S., 2008. Stakeholder Participation for Environmental Management: A Literature Review. Biological Conservation 141:2417-2431.

Reeves, H.W., D.A. Hamilton, P.W. Seelbach, and A.J. Asher, 2009. Ground-Water-Withdrawal Component of the Michigan Water-Withdrawal Screening Tool. U.S. Geological Survey, Reston VA.

Reichert, J.M., M.F. Rodrigues, J.J.Z. Peláez, R. Lanza, J.P.G. Minella, J.G. Arnold, and R.B.L. Cavalcante, 2017. Water Balance in Paired Watersheds with Eucalyptus and Degraded Grassland in Pampa Biome. Agricultural and Forest Meteorology 237-238:282-295.

Rissman, A.R. and C.B. Wardropper, 2020. Adapting Conservation Policy and Administration to Nonstationary Conditions. Society \& Natural Resources 0:1-14.

Robinson, S.C., 2020. Well-Induced Stream Depletion and Groundwater Return Flow: Estimating Impact Schedules with a Finite-Difference Spreadsheet. Journal of Water Resources Planning and Management 146:06020009.

Rohde, M.M., R. Froend, and J. Howard, 2017. A Global Synthesis of Managing Groundwater Dependent Ecosystems Under Sustainable Groundwater Policy. Groundwater 55:293301.

Rohde, M.M., S. Matsumoto, J. Howard, S. Liu, L. Riege, and E.J. Remson, 2018. Groundwater Dependent Ecosystems under the Sustainable Groundwater Management Act: Guidance for Preparing Groundwater Sustainability Plans. The Nature Conservancy, San Francisco, CA.

Ross, A., 2018. Speeding the Transition towards Integrated Groundwater and Surface Water Management in Australia. Journal of Hydrology 567:e1-e10.

Rossman, N.R. and V.A. Zlotnik, 2013. Review: Regional Groundwater Flow Modeling in Heavily Irrigated Basins of Selected States in the Western United States. Hydrogeology Journal 21:1173-1192.

Rouhi Rad, M., E.M.K. Haacker, V. Sharda, S. Nozari, Z. Xiang, A. Araya, V. Uddameri, J.F. 
Suter, and P. Gowda, 2020. MOD\$\$AT: A Hydro-Economic Modeling Framework for Aquifer Management in Irrigated Agricultural Regions. Agricultural Water Management 238:106194.

RRCA, 2003. Republican River Compact Administration Ground Water Model. http://www.republicanrivercompact.org/.

Runge, J., S. Bathiany, E. Bollt, G. Camps-Valls, D. Coumou, E. Deyle, C. Glymour, M. Kretschmer, M.D. Mahecha, J. Muñoz-Marí, E.H. van Nes, J. Peters, R. Quax, M. Reichstein, M. Scheffer, B. Schölkopf, P. Spirtes, G. Sugihara, J. Sun, K. Zhang, and J. Zscheischler, 2019. Inferring Causation from Time Series in Earth System Sciences. Nature Communications 10:2553.

Ruswick, F., J. Allan, D. Hamilton, and P. Seelbach, 2010. The Michigan Water Withdrawal Assessment Process: Science and Collaboration in Sustaining Renewable Natural Resources. Renewable Resources Journal 26:13-18.

Sahoo, S., T.A. Russo, J. Elliott, and I. Foster, 2017. Machine Learning Algorithms for Modeling Groundwater Level Changes in Agricultural Regions of the U.S. Water Resources Research 53:3878-3895.

Saltelli, A., 2019. A Short Comment on Statistical versus Mathematical Modelling. Nature Communications 10:3870.

Saltelli, A., K. Aleksankina, W. Becker, P. Fennell, F. Ferretti, N. Holst, S. Li, and Q. Wu, 2019. Why so Many Published Sensitivity Analyses Are False: A Systematic Review of Sensitivity Analysis Practices. Environmental Modelling \& Software 114:29-39.

Saltelli, A., L. Benini, S. Funtowicz, M. Giampietro, M. Kaiser, E. Reinert, and J.P. van der Sluijs, 2020. The Technique Is Never Neutral. How Methodological Choices Condition the Generation of Narratives for Sustainability. Environmental Science \& Policy 106:8798.

Schmid, W. and R.T. Hanson, 2009. The Farm Process Version 2 (FMP2) for MODFLOW2005- Modifications and Upgrades to FMP1. U.S. Geological Survey, Reston VA.

Schreiner-McGraw, A.P. and H. Ajami, 2020. Impact of Uncertainty in Precipitation Forcing Datasets on the Hydrologic Budget of an Integrated Hydrologic Model in Mountainous Terrain. Water Resources Research:e2020WR027639.

Shen, C., 2018. A Transdisciplinary Review of Deep Learning Research and Its Relevance for Water Resources Scientists. Water Resources Research 54:8558-8593.

Singh, S.K., 2009. Flow Depletion Induced by Pumping Well from Stream Perpendicularly Intersecting Impermeable/Recharge Boundary. Journal of Irrigation and Drainage 
Engineering 135:499-504.

1362 1363

1364 1365

1366

1367 1368

1369 1370

1371

1372

1373

1374

1375

1376

1377

1378

1379

1380

1381

1382 1383

1384 1385 1386

1387 1388

1389

1390

1391

1392 1393

Srinivasan, V. and S. Kulkarni, 2014. Examining the Emerging Role of Groundwater in Water Inequity in India. Water International 39:172-186.

Srinivasan, V., M. Sanderson, M. Garcia, M. Konar, G. Blöschl, and M. Sivapalan, 2017. Prediction in a Socio-Hydrological World. Hydrological Sciences Journal 62:338-345.

Stagge, J.H., D.E. Rosenberg, A.M. Abdallah, H. Akbar, N.A. Attallah, and R. James, 2019. Assessing Data Availability and Research Reproducibility in Hydrology and Water Resources. Scientific Data 6:190030.

Starn, J.J. and K. Belitz, 2018. Regionalization of Groundwater Residence Time Using Metamodeling. Water Resources Research. doi:10.1029/2017WR021531.

Steinman, A.D., J.R. Nicholas, P.W. Seelbach, J.W. Allan, and F. Ruswick, 2011. Science as a Fundamental Framework for Shaping Policy Discussions Regarding the Use of Groundwater in the State of Michigan: A Case Study. Water Policy 13:69-86.

Stisen, S., J. Koch, T.O. Sonnenborg, J.C. Refsgaard, S. Bircher, R. Ringgaard, and K.H. Jensen, 2018. Moving beyond Run-off Calibration-Multivariable Optimization of a SurfaceSubsurface-Atmosphere Model. Hydrological Processes 32:2654-2668.

Taylor, R.G., B. Scanlon, P. Döll, M. Rodell, R. van Beek, Y. Wada, L. Longuevergne, M. Leblanc, J.S. Famiglietti, M. Edmunds, L. Konikow, T.R. Green, J. Chen, M. Taniguchi, M.F.P. Bierkens, A. MacDonald, Y. Fan, R.M. Maxwell, Y. Yechieli, J.J. Gurdak, D.M. Allen, M. Shamsudduha, K. Hiscock, P.J.-F. Yeh, I. Holman, and H. Treidel, 2013. Ground Water and Climate Change. Nature Climate Change 3:322-329.

Theis, C.V., 1941. The Effect of a Well on the Flow of a Nearby Stream. Eos, Transactions American Geophysical Union 22:734-738.

Tolley, D., L. Foglia, and T. Harter, 2019. Sensitivity Analysis and Calibration of an Integrated Hydrologic Model in an Irrigated Agricultural Basin with a Groundwater-Dependent Ecosystem. Water Resources Research. doi:10.1029/2018WR024209.

Traylor, J.P. and V.A. Zlotnik, 2016. Analytical Modeling of Irrigation and Land Use Effects on Streamflow in Semi-Arid Conditions. Journal of Hydrology 533:591-602.

Wahl, K.L. and R.L. Tortorelli, 1997. Changes in Flow in the Beaver-North Canadian River Basin Upstream from Canton Lake, Western Oklahoma. US Department of the Interior. U.S. Geological Survey. https://pubs.usgs.gov/wri/wri964304/.

Walker, G., Q.J. Wang, A.C. Horne, R. Evans, and S. Richardson, 2020a. Estimating Groundwater-River Connectivity Factor for Quantifying Changes in Irrigation Return 
Flows in the Murray-Darling Basin. Australasian Journal of Water Resources:1-18.

Walker, G.R., Q.J. Wang, A. Horne, R. Evans, and S. Richardson, 2020b. Potential Cumulative Impacts on River Flow Volume from Increased Groundwater Extraction under the Murray-Darling Basin Plan. Australasian Journal of Water Resources 0:1-16.

Wardropper, C.B., S. Gillon, and A.R. Rissman, 2017. Uncertain Monitoring and Modeling in a Watershed Nonpoint Pollution Program. Land Use Policy 67:690-701.

Water Sustainability Act, 2014. SBC 2014 c 15. https://canlii.ca/t/54qx7. Accessed 17 Jan 2021.

Wei, X., R.T. Bailey, R.M. Records, T.C. Wible, and M. Arabi, 2019. Comprehensive Simulation of Nitrate Transport in Coupled Surface-Subsurface Hydrologic Systems Using the Linked SWAT-MODFLOW-RT3D Model. Environmental Modelling \& Software 122:104242.

White, J.T., 2017. Forecast First: An Argument for Groundwater Modeling in Reverse. Groundwater 55:660-664.

White, J.T., L.K. Foster, and M.N. Fienen, 2021. Extending the Capture Map Concept to Estimate Discrete and Risk-Based Streamflow Depletion Potential. Groundwater 59:571580.

White, J.T., B. Hemmings, M.N. Fienen, and M.J. Knowling, 2021. Towards Improved Environmental Modeling Outcomes: Enabling Low-Cost Access to High-Dimensional, Geostatistical-Based Decision-Support Analyses. Environmental Modelling \& Software 139:105022.

White, J.T., M.N. Fienen, P.M. Barlow, and D.E. Welter, 2018. A Tool for Efficient, ModelIndependent Management Optimization under Uncertainty. Environmental Modelling \& Software 100:213-221.

White, J.T., M.N. Fienen, and J.E. Doherty, 2016. A Python Framework for Environmental Model Uncertainty Analysis. Environmental Modelling \& Software 85:217-228.

Wilkinson, M.D., M. Dumontier, Ij.J. Aalbersberg, G. Appleton, M. Axton, A. Baak, N. Blomberg, J.-W. Boiten, L.B. da S. Santos, P.E. Bourne, J. Bouwman, A.J. Brookes, T. Clark, M. Crosas, I. Dillo, O. Dumon, S. Edmunds, C.T. Evelo, R. Finkers, A. GonzalezBeltran, A.J.G. Gray, P. Groth, C. Goble, J.S. Grethe, J. Heringa, P.A.C. 't Hoen, R. Hooft, T. Kuhn, R. Kok, J. Kok, S.J. Lusher, M.E. Martone, A. Mons, A.L. Packer, B. Persson, P. Rocca-Serra, M. Roos, R. van Schaik, S.-A. Sansone, E. Schultes, T. Sengstag, T. Slater, G. Strawn, M.A. Swertz, M. Thompson, J. van der Lei, E. van Mulligen, J. Velterop, A. Waagmeester, P. Wittenburg, K. Wolstencroft, J. Zhao, and B. Mons, 2016. The FAIR Guiding Principles for Scientific Data Management and 
Stewardship. Scientific Data 3:160018.

1429

1430

1431

1432

1433

1434

1435

1436

1437

1438

1439

1440

1441

1442

1443

1444

1445

1446

1447

1448

1449

1450

1451

1452

1453

1454

1455

1456

1457

1458

1459

1460

1461

Woolfenden, L.R. and T. Nishikawa, 2014. Simulation of Groundwater and Surface-Water Resources of the Santa Rosa Plain Watershed, Sonoma County, California. US Geological Survey Scientific Investigations Report 2014-5052.

Worland, S.C., W.H. Farmer, and J.E. Kiang, 2018. Improving Predictions of Hydrological LowFlow Indices in Ungaged Basins Using Machine Learning. Environmental Modelling \& Software 101:169-182.

Yarnell, S.M., E.D. Stein, J.A. Webb, T. Grantham, R.A. Lusardi, J. Zimmerman, R.A. Peek, B.A. Lane, J. Howard, and S. Sandoval-Solis, 2020. A Functional Flows Approach to Selecting Ecologically Relevant Flow Metrics for Environmental Flow Applications. River Research and Applications 36:318-324.

Yeh, H.-D., Y.-C. Chang, and V.A. Zlotnik, 2008. Stream Depletion Rate and Volume from Groundwater Pumping in Wedge-Shape Aquifers. Journal of Hydrology 349:501-511.

Zhang, Q., J. Liu, V.P. Singh, X. Gu, and X. Chen, 2016. Evaluation of Impacts of Climate Change and Human Activities on Streamflow in the Poyang Lake Basin, China. Hydrological Processes 30:2562-2576.

Zhao, J., S. Huang, Q. Huang, H. Wang, and G. Leng, 2018. Detecting the Dominant Cause of Streamflow Decline in the Loess Plateau of China Based Onthe Latest Budyko Equation. Water 10:1277.

Zimmer, M.A., K.E. Kaiser, J.R. Blaszczak, S.C. Zipper, J.C. Hammond, K.M. Fritz, K.H. Costigan, J. Hosen, S.E. Godsey, G.H. Allen, S. Kampf, R.M. Burrows, C.A. Krabbenhoft, W. Dodds, R. Hale, J.D. Olden, M. Shanafield, A.G. DelVecchia, A.S. Ward, M.C. Mims, T. Datry, M.T. Bogan, K.S. Boersma, M.H. Busch, C.N. Jones, A.J. Burgin, and D.C. Allen, 2020. Zero or Not? Causes and Consequences of Zero-Flow Stream Gage Readings. WIREs Water:e1436.

Zipper, S.C., J.K. Carah, C. Dillis, T. Gleeson, B. Kerr, M.M. Rohde, J.K. Howard, and J.K.H. Zimmerman, 2019. Cannabis and Residential Groundwater Pumping Impacts on Streamflow and Ecosystems in Northern California. Environmental Research Communications 1:125005.

Zipper, S.C., T. Dallemagne, T. Gleeson, T.C. Boerman, and A. Hartmann, 2018. Groundwater Pumping Impacts on Real Stream Networks: Testing the Performance of Simple Management Tools. Water Resources Research 54:5471-5486.

Zipper, S.C., T. Gleeson, B. Kerr, J.K. Howard, M.M. Rohde, J. Carah, and J. Zimmerman, 2019. Rapid and Accurate Estimates of Streamflow Depletion Caused by Groundwater 
Pumping Using Analytical Depletion Functions. Water Resources Research 55:58075829.

Zipper, S.C., T. Gleeson, Q. Li, and B. Kerr, 2021. Comparing Streamflow Depletion Estimation Approaches in a Heavily-Stressed, Conjunctively-Managed Aquifer. Water Resources Research:e2020WR027591.

Zipper, S.C., J.C. Hammond, M. Shanafield, M. Zimmer, T. Datry, C.N. Jones, K.E. Kaiser, S.E. Godsey, R.M. Burrows, J.R. Blaszczak, M.H. Busch, A.N. Price, K.S. Boersma, A.S. Ward, K. Costigan, G.H. Allen, C.A. Krabbenhoft, W.K. Dodds, M.C. Mims, J.D. Olden, S.K. Kampf, A.J. Burgin, and D.C. Allen, 2021. Pervasive Changes in Stream Intermittency across the United States. Environmental Research Letters 16:084033.

Zipper, S.C., M. Motew, E.G. Booth, X. Chen, J. Qiu, C.J. Kucharik, S.R. Carpenter, and S.P. Loheide II, 2018. Continuous Separation of Land Use and Climate Effects on the Past and Future Water Balance. Journal of Hydrology 565:106-122.

Zipper, S.C., M.E. Soylu, C.J. Kucharik, and S.P. Loheide II, 2017. Quantifying Indirect Groundwater-Mediated Effects of Urbanization on Agroecosystem Productivity Using MODFLOW-AgroIBIS (MAGI), a Complete Critical Zone Model. Ecological Modelling 359:201-219.

Zipper, S.C., K. Stack Whitney, J.M. Deines, K.M. Befus, U. Bhatia, S.J. Albers, J. Beecher, C. Brelsford, M. Garcia, T. Gleeson, F. O’Donnell, D. Resnik, and E. Schlager, 2019. Balancing Open Science and Data Privacy in the Water Sciences. Water Resources Research 55:5202-5211.

Zlotnik, V.A., 2015. Analytical Methods for Assessment of Land-Use Change Effects on Stream Runoff. Journal of Hydrologic Engineering 20:06014009.

Zlotnik, V.A. and D.M. Tartakovsky, 2008. Stream Depletion by Groundwater Pumping in Leaky Aquifers. Journal of Hydrologic Engineering 13:43-50. 